\title{
The DAV and Periadriatic fault systems in the Eastern Alps south of the Tauern window
}

Received: 6 March 2000 / Accepted: 15 November 2000 / Published online: 15 March 2001

(C) Springer-Verlag 2001

\begin{abstract}
Alpine deformation of Austroalpine units south of the Tauern window is dominated by two kinematic regimes. Prior to intrusion of the main Periadriatic plutons at $\sim 30 \mathrm{Ma}$, the shear sense was sinistral in the current orientation, with a minor northside-up component. Sinistral shearing locally overprints contact metamorphic porphyroblasts and early Periadriatic dykes. Direct $\mathrm{Rb}-\mathrm{Sr}$ dating of microsampled synkinematic muscovite gave ages in the range 33-30 Ma, whereas pseudotachylyte locally crosscutting the mylonitic foliation gave an interpreted ${ }^{40} \mathrm{Ar}-{ }^{39} \mathrm{Ar}$ age of $\sim 46 \mathrm{Ma}$. The transition from sinistral to dextral (transpressive) kinematics related to the Periadriatic fault occurred rapidly, between solidification of the earlier dykes and of the main plutons. Subsequent brittle-ductile to brittle faults are compatible with N-S to NNW-SSE shortening and orogen-parallel extension. Antithetic Riedel shears are distinguished from the previous sinistral fabric by their finegrained quartz microstructures, with local
\end{abstract}

\footnotetext{
N. S. Mancktelow (®) · W. Müller $\cdot$ G. Viola - D. Seward Department of Earth Sciences, ETH-Zentrum, 8092 Zurich, Switzerland

E-mail: mancktelow@erdw.ethz.ch

Phone: +41-1-6323671

Fax: +41-1-632-1030

D. F. Stöckli

Division of Geological and Planetary Sciences,

Mail Stop 100-23, California Institute of Technology,

Pasadena, CA 91125, USA

B. Grollimund

Department of Geophysics, Stanford University,

Stanford CA94305, USA

B. Fügenschuh

Geologisch-Paläontologisches Institut, Universität Basel, Bernoullistrasse 32, 4056 Basel, Switzerland

I. M. Villa

Mineralogisch-Petrographisches Institut, Universität Bern, Baltzerstrasse 1, 3012 Bern, Switzerland
}

pseudotachylyte formation. One such pseudotachylyte from Speikboden gave a ${ }^{40} \mathrm{Ar}-{ }^{39} \mathrm{Ar}$ age of $20 \mathrm{Ma}$, consistent with pseudotachylyte ages related to the Periadriatic fault. The magnitude of dextral offset on the Periadriatic fault cannot be directly estimated. However, the jump in zircon and apatite fission-track ages establishes that the relative vertical displacement was $\sim 4-5 \mathrm{~km}$ since $24 \mathrm{Ma}$, and that movement continued until at least $13 \mathrm{Ma}$.

Keywords Eastern Alps - Periadriatic fault - DAV . Tectonics $\cdot$ Microstructure $\cdot$ Geochronology

\section{Introduction}

The Periadriatic fault is one of the most prominent features on any regional map of the Alps. It is taken, by definition, to represent the tectonic boundary separating the Southern Alps, with a weak Alpine structural and metamorphic overprint, from the more strongly affected Western, Central and Eastern Alps. However, when considered more critically, this distinction is not so straightforward (e.g. see discussion in Schmid et al. 1989). The definition is clearest in the central segment between Val d'Ossola (NW Italy) and Val Bregaglia/Bergell (SE Switzerland, Italy), where there is an important jump in the present depth of exhumation, with amphibolite facies to the north juxtaposed against Alpine anchizonal to epizonal metamorphism to the south. Exhumation in the Central Alps north of the Periadriatic fault has produced the broad Lepontine metamorphic dome of Tertiary age (e.g. Bradbury and Nolen-Hoeksema 1985; Merle et al. 1989). With decreasing depth of exhumation both east and west of this culmination, the definition of the Periadriatic fault on the basis of Alpine metamorphism becomes more problematic. As the youngest major Alpine fault, the Periadriatic fault locally cuts out older Cretaceous and Tertiary structures, so that 


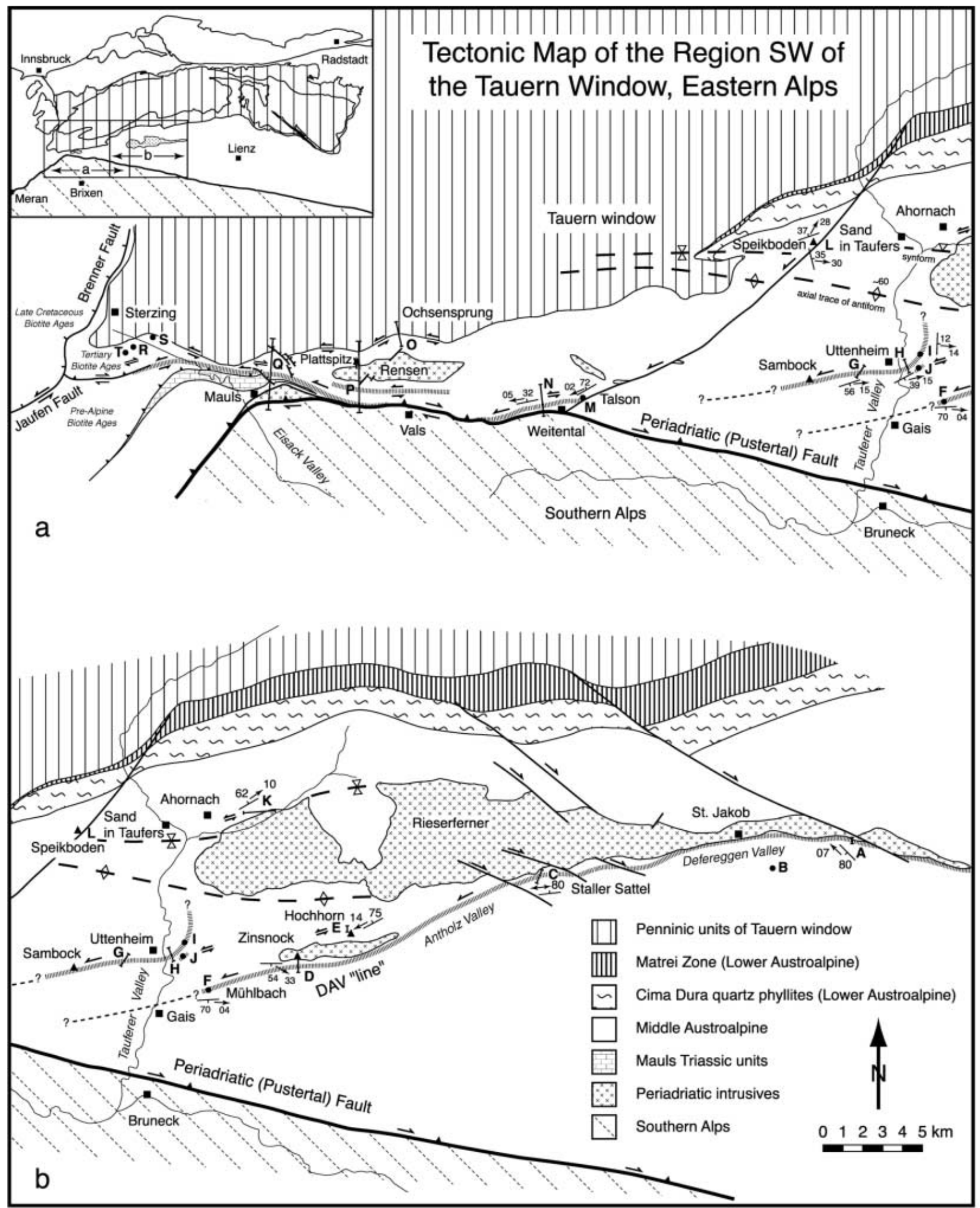

Fig. 1 Regional map of the Austroalpine south of the Tauern window, with locations referred to in the text indicated by bold letters. Note that the DAV "line" as indicated corresponds to the southern limit of heterogeneous Alpine sinistral overprint and is gradational to the north; the same applies to the dextral overprint in the western area around Mauls-Sterzing, where there is a pervasive but heterogeneous overprint north of the Mauls Triassic units. Outcrop conditions are poor immediately north of the Periadriatic fault between Weitental and the Tauferer valley and correlation of individual mylonite zones is uncertain, as indicated by question marks 
the jump in metamorphism and consequent structural style represents a finite effect of both these previous movements and the movement on the Periadriatic fault itself. In particular, in the region south of the Tauern window (Fig. 1), the main jump in Alpine metamorphic grade (and hence in mineral ages) is reported to occur across the Defereggen-Anterselva/ Antholz-Valles/Vals (DAV) fault (Bianchi 1934; Dal Piaz 1934; Borsi et al. 1973), to the north of the Periadriatic fault (Fig. 1). Both Tertiary and Cretaceous ages are reported for different isotopic mineral systems north of the DAV, whereas to the south pre-Alpine ages are preserved (Borsi et al. 1973, 1978a; Stöckhert et al. 1999). Rather than a clear jump in metamorphism, the Periadriatic fault (locally known as the Pustertal fault or Pusteria line) is defined here as a mappable boundary between typical Austroalpine gneisses (often referred to as the "Altkristallin" or old crystalline in the German-speaking literature) and the effectively undeformed Permian Brixen granodiorite and low-grade Paleozoic Brixen "quartz phyllites" of the Southern Alps. Although the width of the Periadriatic fault can vary locally up to several hundred metres, it is usually marked by a narrow zone (often less than $1 \mathrm{~m}$ ) of (ultra-) cataclasite, responsible for the clear topographic expression. Elongate lamellae of Oligocene tonalites (e.g. Martin et al. 1993) and slices of low-grade Permo-Triassic sediments occur discontinuously along the fault zone. Only further west, near Vals, where the DAV is cut out by the Periadriatic fault, is a jump in Alpine metamorphism re-established across the Periadriatic fault itself (Fig. 1).

This paper considers the kinematics and relative age relationships of deformation south of the Tauern window, with particular reference to the DAV and Periadriatic faults. It summarizes several years of work involving both diploma and doctorate studies of field aspects, microstructure and geochronology. It should be considered a summary of current knowledge providing a basis for further study, since many aspects are still not completely resolved. This is in part because of the variable outcrop conditions. However, it is also because of the urgent need for additional texturally controlled geochronological data on structures of similar field and microstructural aspect but potentially different age.

\section{Dating fault movement}

In this paper, the term "fault" is used in a general way to cover any zone across which there is important relative displacement, whether it is a broad ductile shear zone or a more discrete brittle structure. In particular, the DAV has often been represented on sketch maps as a single discrete line (and indeed in the literature sometimes to referred to as a "line"), whereas in reality it is a gradational zone with a finite width of hundreds of metres. The line on the map of
Fig. 1 represents only the gradational southern limit to the southernmost shear zone, with many similar shear zones heterogeneously developed further to the north.

Another concept that must be abandoned is the idea of a specific "age" for any particular fault. In principle at least, it might be possible to establish a time for the initiation of a particular structure, but it is clear from field relationships and geochronological results that once a fault exists it can be reactivated many times. As long as a pre-existing fault remains weaker than its surroundings, strain is preferentially concentrated in the zone irrespective of whether the deformation is continuous or interrupted by periods of little activity. It is therefore typical that more than one "age" can be obtained from a single fault. Results presented herein derive both from more "direct" methods of dating deformation (e.g. formation ages of synkinematically grown minerals; Müller 1998; Müller et al. 2000) and indirect constraints, such as the intrusion age of crosscutting or deformed dykes (Müller et al. 2000; Müller et al., 2001) or relating the age and "closure temperature" of different mineral systems to the observed microstructure. Ages from pseudotachylytes, using ${ }^{40} \mathrm{Ar}-{ }^{39} \mathrm{Ar}$ stepwise-heating and laser-ablation methods, also provide reliable estimates of the time of their formation as (micro-) seismic events (Sibson 1975), if critically applied and evaluated (e.g. Kelley et al. 1994; see Müller 1998 for details of the technique). In cases where pseudotachylyte veins crosscut a pre-existing mylonitic foliation they provide minimum ages for this fabric. They may also be partially smeared out into the mylonites and themselves foliated, demonstrating that they were developed due to local higher strain-rate pulses in fault zones close to the brittle-ductile transition (e.g. Magloughlin and Spray 1992).

\section{Regional tectonic framework}

The Austroalpine gneiss zone Meran-Mauls-Bruneck (Sander 1929) to the south of the Tauern window has been through several major orogenic cycles (e.g. Borsi et al. 1973; Sassi et al. 1974; Stöckhert 1982, 1985, 1987; Frisch et al. 1984; Neubauer et al. 1999). In the latter part of the immediately pre-Alpine Hercynian (or Variscan) cycle, a major period of magmatic activity occurred, with plutons spanning a wide range of compositions (from gabbroic to tonalitic/granodioritic) intruded into different crustal levels of the Austroalpine gneisses. The youngest of these range down into the Permian (e.g. Del Moro and Notarpietro 1987) and the latest of all are tourmaline-bearing pegmatites developed around $260 \mathrm{Ma}$ (e.g. Borsi et al. 1980). Shear zones related to rifting and crustal thinning at the termination of the Hercynian cycle locally overprint the Permian intusives (e.g. Schuster et al. 1999; Müntener et al. 2000), including the pegmatites (Mancktelow et al. 1999). Extensional faults also 
developed during the subsequent period of Mesozoic (mainly lower Jurassic) rifting and passive margin formation (e.g. Froitzheim and Eberli 1990; Manatschal 1999). Only isolated and incomplete remnants of Mesozoic sediments are preserved in the region of study, the most important of which occurs in the region of Mauls (Fig. 1).

The Meran-Mauls-Bruneck gneiss complex corresponds to the Middle Austroalpine in the sense of Tollmann (1959, 1963, 1977). It continues to the west as the contiguous Texel group, Schneeberg complex and Ötztal-Stubai crystalline (together with its socalled Brenner Mesozoic cover) west of the Brenner pass. The Ötztal-Stubai crystalline and Brenner Mesozoic preserve a Cretaceous metamorphism increasing in grade to upper amphibolite facies in a SE direction (e.g. Hoinkes et al. 1982; Thöni 1981). Locally in the region immediately north of Meran, the older crystalline units contain eclogites of probable Cretaceous age (Hoinkes et al. 1991). Mineral growth in much of the complex outlasted deformation, so that random biotite growth overprinting the foliation and fairly well-tempered quartz fabrics are characteristic of this zone of higher-grade Cretaceous metamorphism. The region was exhumed as the footwall to a major Late Cretaceous-Early Tertiary, low-angle top-to-ESE normal fault (Fügenschuh and Rockenschaub 1993; Fügenschuh 1995; Fügenschuh et al., 2000). In contrast to the main footwall region, dynamic microstructures are still preserved in mylonites from the broad fault zone. The hanging wall to this fault is composed of the low metamorphic grade Steinach and Blaser nappes, here representing the Upper Austroalpine of Tollmann (1959, 1963).

Within the Austroalpine domain, Penninic units are currently only exposed within antiformal windows (Engadine, Tauern, Rechnitz) related to Tertiary exhumation in the footwall of low-angle normal faults (e.g. Behrmann 1988; Selverstone 1988; Genser and Neubauer 1988; Ratschbacher et al. 1990, 1991a, 1991b; Dunkl and Demeny 1997; Fügenschuh et al. 1997). A maximum age for the relative overthrusting of the Austroalpine over the Penninic units is given by the youngest sediments exposed in these windows. In the Engadine window, these reach up to the Eocene (Rudolph 1982; Waibel and Frisch 1989), but no sediments of Tertiary age are known from the Tauern window.

Tertiary intrusions are concentrated on or close to the Periadriatic fault (hence the name "Periadriatic intrusives"; e.g. Laubscher 1983; Martin et al. 1993; von Blanckenburg et al. 1998). They extend from Traversella and Biella near Torino (NW Italy) in the west to the edge of the Pannonian basin (N Slovenia) in the east. The Adamello composite batholith shows a progression in intrusion ages from $\sim 42 \mathrm{Ma}$ in the south to $\sim 30 \mathrm{Ma}$ in the north (e.g. Del Moro et al. 1983), but most of the tonalitic intrusives and calc-alkaline dykes closely related to the Periadriatic fault appear to have intruded at a very similar time around 30-32 Ma. However, even within this short time span there is a consistent relative chronology of intrusion in the region considered here (Scolari and Zirpoli 1972; Mager 1985; Grollimund 1996). The sequence, from older to younger is: (1) porphyritic ( 1 mm feldspar \pm white mica \pm biotite) tonalitic to granodioritic dykes that are not observed within the main plutonic bodies, are locally strongly deformed and, when adjacent to the main plutons, are subsequently contact-metamorphosed; (2) the main tonalitic to granodioritic intrusions (Rensen, Rieserferner); (3) granitic, aplitic, pegmatitic and quartz veins that are particularly common in and around the plutons; and (4) late, crosscutting, fine-grained mafic dykes and hornblende-bearing "lamprophyres". This temporal sequence of distinctive intrusions has been critical in this study for establishing an important change in regional tectonics, from sinistral to dextral, between group (1) early dykes and solidification of the group (2) plutons. The numbering scheme 1-4 is used consistently herein when referring to these distinctive groups of intrusions.

From this brief overview of the regional tectonic history, five markers that are important for determining the relative timing of events in the Austroalpine south of the Tauern window are established:

1. The characteristic Permian pegmatites around $260 \mathrm{Ma}$

2. The Mesozoic sedimentary cover of the pre-Alpine basement

3. The contact to the Mesozoic Penninic units of the Tauern window

4. The common dykes and larger Mauls, Rensen and Rieserferner plutons, representing the Oligocene "Periadriatic intrusives", together with their associated metamorphic aureoles

5. The exhumation and updoming of the Tauern window

Unfortunately, it is also clear that the time span covered by these constraints is large (over $200 \mathrm{Ma}$ ). Further constraint is provided by overprinting relationships between folds and foliations or by crosscutting shear zones, but this requires assumptions with regard to regional correlation of individual structures. Estimation of metamorphic conditions associated with particular microstructures (e.g. transition in deformation and recrystallization mechanism of quartz or fracture vs crystal plasticity and recrystallization in feldspar) combined with isotopic mineral ages also provides some constraint. However, the precision involved is limited by uncertainties in temperature estimates for the microstructural transitions (especially difficult for minerals of varying composition, such as feldspar) and on the necessary absence of subsequent recrystallization. 


\section{Deformation history in the Austroalpine and adjacent Tauern window}

The Austroalpine units between the Periadriatic fault and the Tauern window are characterized by the distinctly heterogeneous development of shear zones and folds. However, the orientation of the structural elements is rather constant, dominated by an ENE strike of the foliation with a more variable but generally steep dip, and stretching, intersection and fold axis lineations that are near horizontal (Fig. 1). Where determinable, the sense of shear is remarkably consistent and sinistral. The exceptions to these observations are the youngest features broadly related to movement on the Periadriatic fault and exhumation of the Tauern window. The increasing depth of exhumation towards the Tauern window is reflected in a progression in structural style and microstructure towards the NNW. The Periadriatic fault itself strikes E to ESE, with the result that the older ENE striking features are progressively cut out or thinned to the west and the distance to the Tauern window boundary and the Penninic units decreases. It follows that the progression in structures observable from the Periadriatic fault to the Tauern Window is foreshortened in the west towards Mauls, and the effects of Periadriatic fault movements and Tauern window exhumation strongly overprint the previous structural history (Stöckli and Fügenschuh 1995). It also follows that in general the older history is easier to decipher in the east and the younger history in the west where, at the exposed level, temperature was higher at the start of the Oligocene-Neogene history.

Reflecting the different depth and timing of exhumation, there is a progression in mineral ages getting younger both northward towards the Tauern window and towards the west. The transition from pre-Alpine to Alpine biotite ages was originally used by Borsi et al. (1973) to define the position of the DAV. However, the location of the transition in mineral age moves progressively south for different mineral chronometers, as the stability of minerals to isotope exchange (Villa 1998) or annealing decreases from Sr in muscovite all the way to apatite fission track (e.g. Stöckhert et al. 1999), where the jump only occurs at the Periadriatic fault itself (e.g. Grundmann and Morteani 1985).

Unravelling the tectonic history of the Austroalpine south of the Tauern window involves the stepwise removal of events going backwards in time, using the non-pervasive character of the overprint to look further and further back. For this reason, the description here first considers the younger Periadriatic events and then considers the previous structures broadly related to the DAV.

\section{The Periadriatic fault system}

Initiation of the Periadriatic fault itself was in the mid-Oligocene, coeval with intrusion of the immediately adjacent tonalite lamellae to the north (e.g. Martin et al. 1993). Activity during intrusion can be established, for example, in the Mauls tonalite, which develops (particularly towards the southern contact) a magmatic to submagmatic foliation parallel to the trend of the Periadriatic fault (Stöckli 1995). Although the foliation is well defined, lineation development is weak. This suggests oblate finite strain geometry consistent with transpression rather than strictly strike-slip movement. It may also reflect a deformation-induced component of forced radial intrusion, the sideways component leading to the typical elongate form of all these "lamellae" along the trace of the Periadriatic fault. As discussed below, the kinematics immediately prior to intrusion of the Periadriatic plutons was different and there is no evidence for previous dextral activity on the Periadriatic fault in its current position.

The period since the mid-Oligocene is marked by lateral extrusion of the Eastern Alps (e.g. Ratschbacher et al. 1989, 1991a, 1991b; Decker and Peresson 1996) and associated exhumation of the antiformal Tauern window bounded by low-angle normal faults at its western (Brenner fault; Behrmann 1988; Selverstone 1988) and eastern (Genser and Neubauer 1988) ends. The main period of exhumation along the Brenner fault was approximately 20-17 Ma, during which the core of the antiformal dome was exhumed vertically by approximately $20 \mathrm{~km}$ (Fügenschuh 1995; Fügenschuh et al. 1997). This large relative displacement produced a broad zone of mylonites in the immediate footwall that record deformation under decreasing temperature conditions during progressive exhumation. On the regional scale, one component of the mylonites was folded around the nose of the major antiform at Sterzing (Stöckli 1995), whereas a younger (and larger) component continues more-or-less straight on into the Jaufen fault (Fig. 1, as already suggested by Selverstone 1988). Low-angle normal faulting during coeval antiformal doming leads to a maximum in the depth of exhumation along the crest of the antiform, progressively decreasing in magnitude towards the flanks (i.e. to north and south for the Tauern window). Several important effects extend into the region of interest in this paper:

1. There is a gradient in depth of exhumation from the border of the Tauern window to the south, which is reflected in the mineral ages and in the metamorphism, microstructure and deformation style of all previous events. Along a N-S profile on the eastern flank of the Eisack valley, fission-track ages increase from 14-15 Ma for zircon and $9 \mathrm{Ma}$ for apatite to $24 \mathrm{Ma}$ for zircon and $13 \mathrm{Ma}$ for apatite towards the south (Fig. 2; Fügenschuh 1995; Stöckli 1995). The density of sampling is not suffi- 


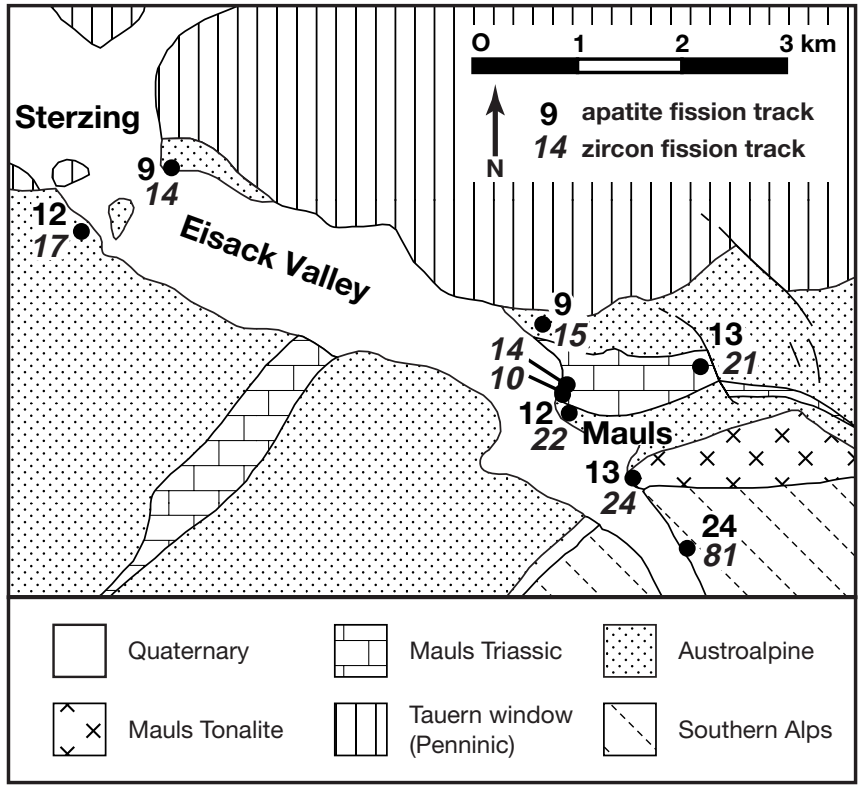

Fig. 2 Zircon (italics) and apatite (roman) fission-track ages in the SW Tauern window area, to either side of the Eisack valley south of Sterzing. Original data from Fügenschuh (1995) and Stöckli (1995)

cient to establish if the variation is smooth or, as is suspected, stepped in relation to discrete south-directed reverse faults (see item 4 below). The most striking feature is the abrupt increase in ages, for both zircon and apatite, across the Periadriatic fault on the southern side of the Mauls tonalite lamella. One sample from the Brixen granodiorite (intrusion age $281 \pm 6 \mathrm{Ma}$; Borsi et al. 1972) gave a zircon fission-track age of $81 \mathrm{Ma}$ and an apatite age of $24 \mathrm{Ma}$. Since the zircon ages to the north of the Periadriatic fault are the same as the apatite ages to the south, namely $24 \mathrm{Ma}$, and samples were taken from almost the same elevation, the amount of relative vertical displacement since $24 \mathrm{Ma}$ can be estimated from the geothermal gradient at $24 \mathrm{Ma}$ and the difference in closure temperature for the two systems. For reasonable assumptions $\left(120-150^{\circ} \mathrm{C}\right.$ difference in closure temperature, $25-30^{\circ} \mathrm{C} / \mathrm{km}$ average geothermal gradient) this results in approximately $4-5 \mathrm{~km}$ uplift of the Austroalpine relative to the Southern Alps since $24 \mathrm{Ma}$, with displacement continuing until at least $13 \mathrm{Ma}$.

2. Previous structures may be folded and rotated during exhumation of the window. In particular, the southern boundary of the Tauern window is overturned north of Mauls, becoming vertical further east and then eventually dipping steeply SSE to the east of the Rensen area. However, it is striking in the field that the angular relationship between the transected older foliation and the Periadriatic dykes, dated at approximately $30 \mathrm{Ma}$ (see below), is remarkably consistent, both in the Austroalpine
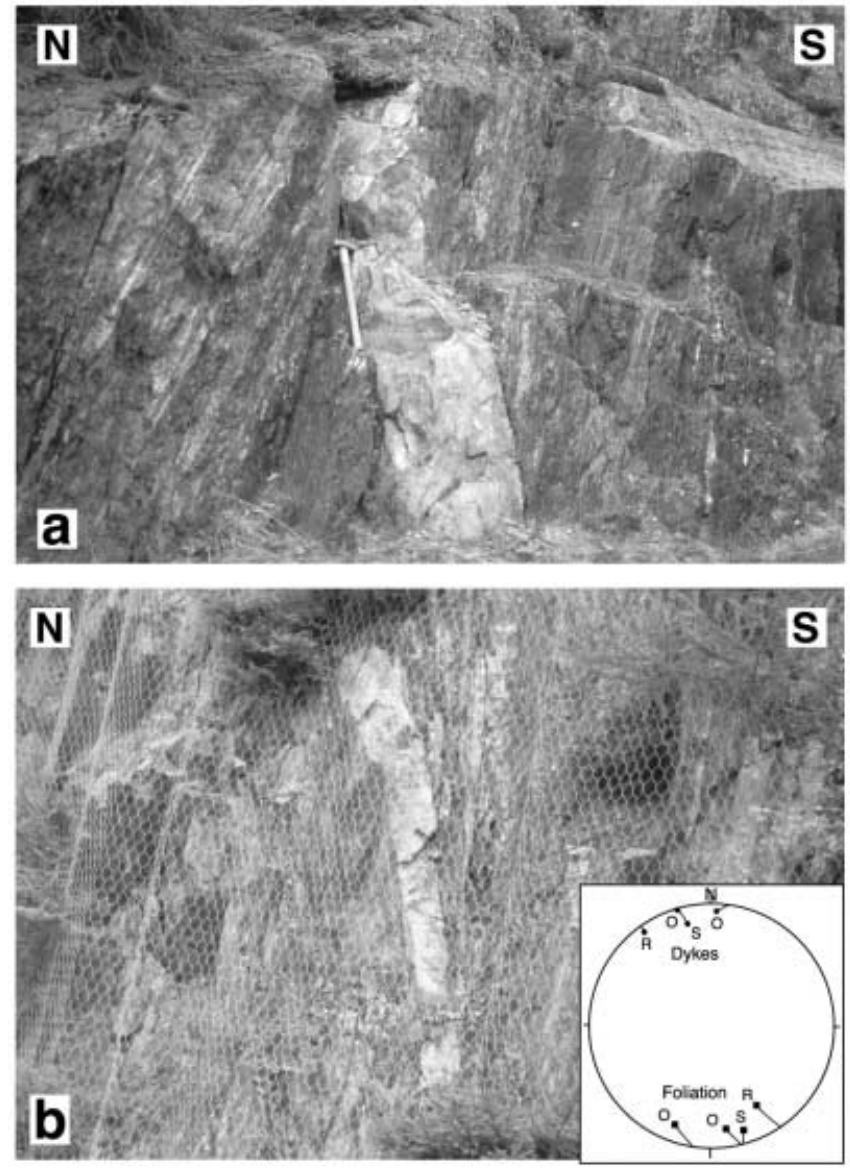

Fig. 3a, b Mid-Oligocene dyke orientation relative to the dominant foliation in the Austroalpine paragneiss, schist and amphibolite a looking ENE, on the Ochsensprung road (foliation in country rock 020/75 (dip direction/dip), lineation 299/18, dyke wall 183/83, location immediately above the highest hairpin bend on the road at $\sim 1650 \mathrm{~m}$ ), and b on the Penserjoch road (location T, Fig. 1) immediately on strike from the Reifenstein castle (width of dyke $\sim 30 \mathrm{~cm}$, foliation in country rock $320-330 / 80-85$, lineation $235-250 / 10-20)$. Note that $\mathbf{b}$ is a mirror image of the actual outcrop view (looking W), for direct comparison with a. Representative orientation data in the lower hemisphere equal area stereoplot are from Ochsensprung $(\mathrm{O})$, Reifenstein (R) and Sprechenstein (S; see Fig. 1)

and the adjacent Tauern window. In the southwest corner of the Tauern window, where both the contact to the Tauern window and the concordant foliation are overturned (i.e. dipping to the NNW), the dykes themselves are nearly vertical or dip steeply SSE (Fig. 3). The simplest interpretation is that both the Tauern window contact and the concordant foliation had a steep to overturned orientation before the mid-Oligocene, that the dykes intruded in a near vertical orientation, and that there has been little rigid-body rotation of the dykes since their emplacement. The southern steep zone north of the Periadriatic fault therefore already existed prior to $30 \mathrm{Ma}$. 

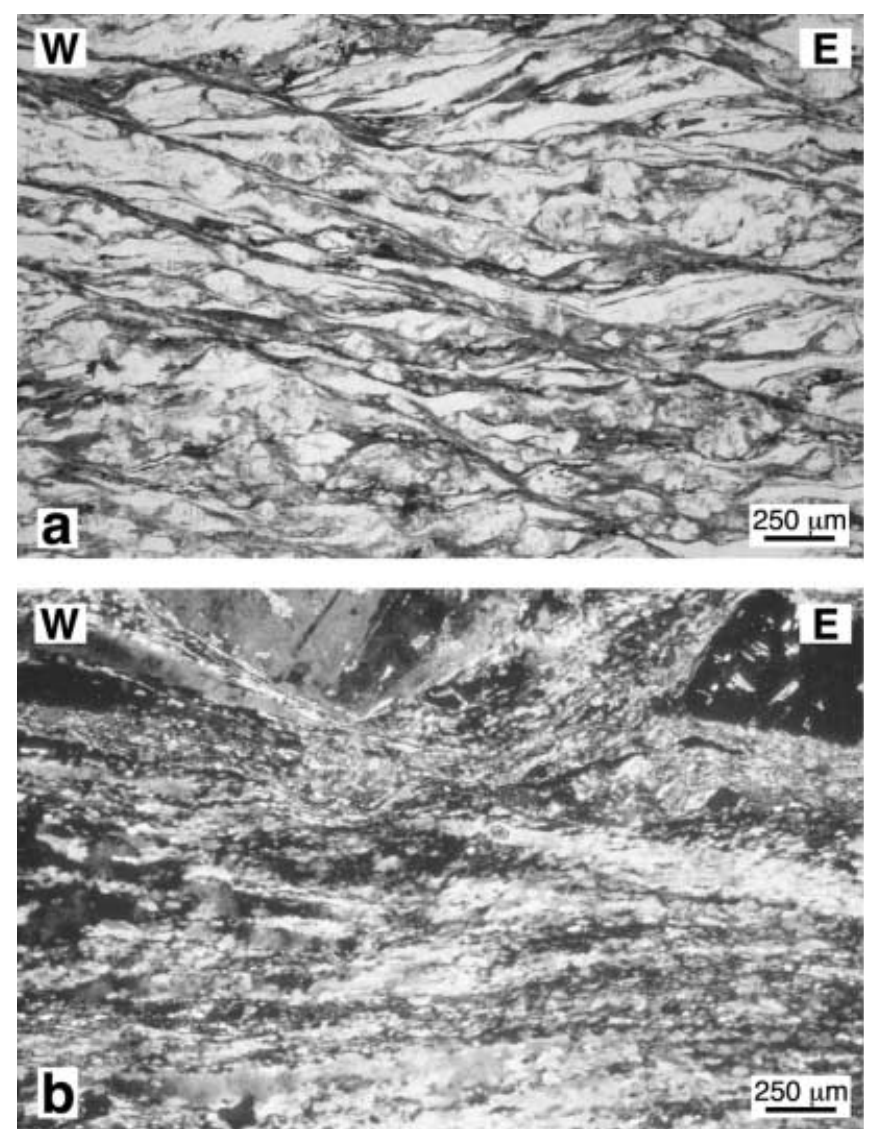

Fig. 4a, b Dextral overprint of the northern Rensen pluton contact near Plattspitz (Fig. 1; coordinates 1.697.190/5.193.250, 1:10,000 grid of South Tyrol, $2550 \mathrm{~m}$ elevation). Foliation 015/76, lineation 115/00. a Austroalpine from $20 \mathrm{~cm}$ north of the contact itself. b Adjacent mylonitized Rensen tonalite

3. The component of Brenner fault movement folded around the antiform at Sterzing is seen as common greenschist-facies mylonites with a consistent dextral shear sense overprinting all older structures, including the Oligocene Periadriatic intrusives (Fig. 4). The overprint is largely restricted to the immediate footwall of the Brenner fault in the region of Sterzing and Mauls (Fig. 1). The component folded around the nose of the antiform near Sterzing transfers to the Periadriatic fault (or is in part cut out by still younger brittle movement on the Periadriatic fault) to the east of Mauls (Stöckli 1995). Further eastward, broadly distributed dextral ductile mylonite zones were not observed north of the Periadriatic fault, but only more discrete structures developed close to the brittle-ductile transition or distinct brittle faults (see item 4 below).

4. Later discrete brittle-ductile to brittle faults crosscut and offset the previous mylonites. When still (semi-) ductile, they are narrow $(<1 \mathrm{~m}$ to only centimetres wide) and, in quartz-rich rocks, grain-size reduction by subgrain rotation recrystallization produces a very fine grain size $(\leq 5 \mu \mathrm{m})$. The pres-

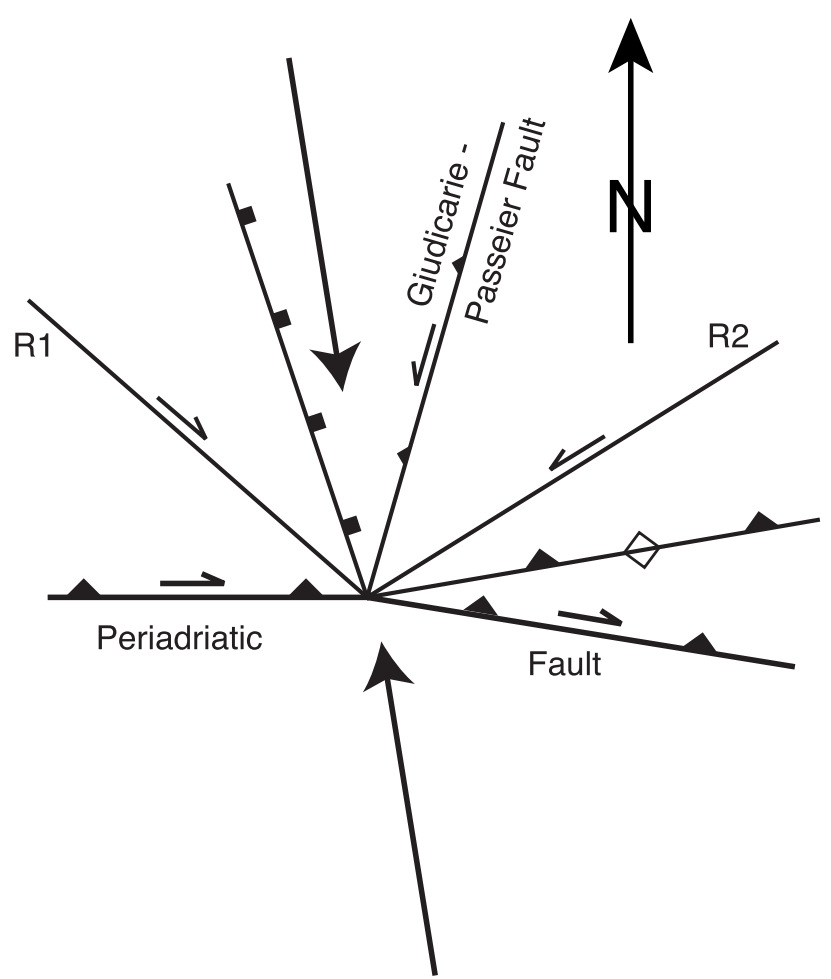

Fig. 5 Summary of fault orientations related to the dextral transpressive Periadriatic fault system from the Mauls-PlattspitzOchsensprung area (original data in Stöckli 1995 and Grollimund 1996)

ervation of such a fine grain size is characteristic of these younger structures, since it could not have been preserved unless subsequent temperatures remained low. The faults have several common orientations: (a) top-to-S or SE steep reverse faults, often faulting out the limbs of kinky folds representing the continuation of the north-south shortening (e.g. the northern tectonic boundary to the Mauls Triassic units); (b) top-to-E or ENE steep normal faults, sometimes with a minor dextral component (Fig. 1); and (c) common NE- to NNEstriking sinistral strike-slip faults, the most important regional example of which is the Passeier-Giudicarie fault (see also the contact of the Rensen pluton; Fig. 1). Fault analysis of all these structures and associated striae (Stöckli 1995, Grollimund 1996, following Marrett and Allmendinger 1990) indicate that they are all compatible with a N-S to NNW-SSE shortening direction and coeval E-W extension (e.g. Fig. 5), the same tectonic framework as required for development of the Tauern window (e.g. Fügenschuh et al. 1997).

5. Coeval displacement continued on the Periadriatic fault itself. Field evidence for the direction and sense of displacement is rare in the area of this study, although a dextral plus north-side-up sense is generally assumed from observations made further east (e.g. Polinski and Eisbacher 1992; Fodor et al. 


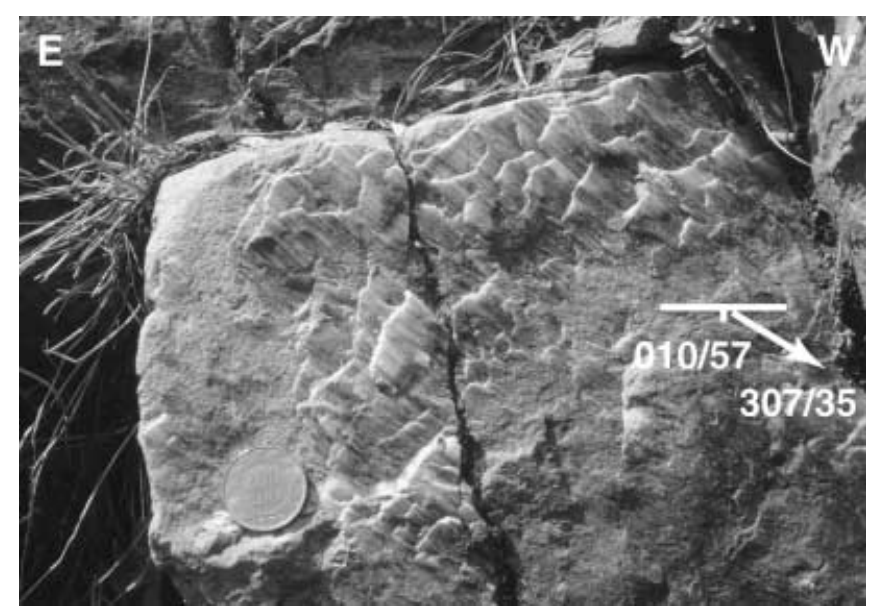

Fig. 6 Stepped slickenfibres indicating dextral transpressive reactivation of the southernmost limit to the DAV mylonites, south of Zinsnock (location D, Fig. 1)

1998). Associated with the Periadriatic fault are both synthetic and antithetic Riedel faults (R1 and R2 on Fig. 5), with the synthetic Riedels dominant (Fig. 1). Previous fault zones (such as the DAV discussed below) are reactivated as cataclastic zones and on discrete fault planes with stepped fibres indicating dextral plus north side up (Fig. 6). This reactivation is at least in part responsible for the jump in mineral ages across the previously defined DAV "line", similar to the jump observed across the Periadriatic fault itself.

${ }^{40} \mathrm{Ar}-{ }^{39} \mathrm{Ar}$ dating of associated pseudotachylytes provides additional time constraint on the brittle (coseismic) history of faults related to the Periadriatic system. For the Periadriatic fault itself, Müller et al. (2001) report an age of $26.9 \pm 0.8 \mathrm{Ma}$ (sample JP82) from within the continuation of the Mauls tonalite lamella to the west and $\sim 20-22 \mathrm{Ma}$ (sample PAL35B) from the Archerlabach gorge section through the Periadriatic fault to the east, near Liesing in Lesachtal (SW Austria). A similar result of $25.5 \pm 0.9 \mathrm{Ma}$ (sample DAV8) was also obtained on a pseudotachylyte $1.5 \mathrm{~km}$ south of the DAV in Defereggen valley (location B, Fig. 1), consistent with field observations that the DAV was locally reactivated during Periadriatic fault displacement. K-Ar ages determined by Frank et al. (1977) and Hammerschmidt (1982) on the fine white mica size fraction from the basal siliciclastics of the Mauls Permo-Triassic are in the range 15-22 Ma. Stöckli (1995) suggested that these results may not represent regional cooling ages but neocrystallization ages dating penetrative deformation related to southdirected folding and thrusting coeval with the Periadriatic fault.

The NNE-trending sinistral cataclastic faults appear to be somewhat younger, since the most important example, the Giudicarie-Passeier fault, offsets both the main Periadriatic fault and the mylonites of the

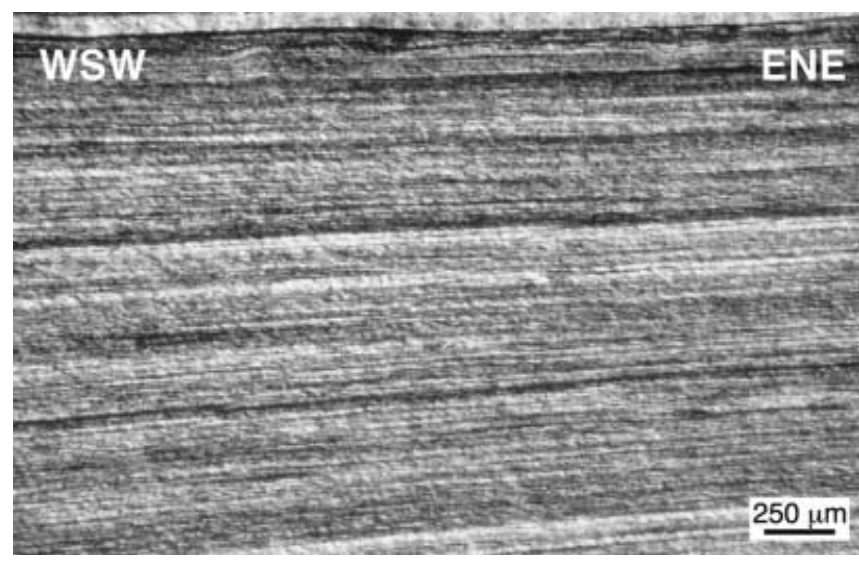

Fig. 7 Quartz fabric from Speikboden (locality L, Fig. 1). The dated pseudotachylyte of Fig. 8 was taken from the same outcrop. Foliation 341/37, lineation 030/28

Jaufen fault (Mancktelow et al. 1999; Viola 2000). Müller et al. (2001) report an age of $17.3 \pm 1.1 \mathrm{Ma}$ (sample JAU13) from a pseudotachylyte immediately adjacent to the Passeier fault near Gfeis ( $\mathrm{N}$ of Meran). Pseudotachylytes from the Jaufen fault gave ages of $16.9 \pm 0.8 \mathrm{Ma}$ (sample JAU 10 ) and $21.0 \pm 1.5 \mathrm{Ma}$ (sample JAU34A). This is consistent with the proposed age of the main Brenner and Jaufen fault movements in the range 20-17 Ma (Fügenschuh et al. 1997), which is considered by many authors as the time of initiation and greatest activity of eastward lateral escape of crustal wedges from the Eastern Alps into the Pannonian area (e.g. Decker and Peresson 1996).

As noted in the Introduction, the deformation fabrics in the Austroalpine in general trend ENE and have a typically sinistral shear sense. Distinguishing between these older fabrics and possible antithetic Riedels to the Periadriatic fault system is not always easy. On the crest of the Speikboden ridge (location L, Fig. 1), a narrow zone of ultramylonite and associated pseudotachylyte crops out, which, in the field, was assumed to be part of the "Speikboden mylonites" discussed below as part of the general DAV system. However, although the sense of shear is clearly sinistral, preservation of the very fine grain size of this quartz-mylonite (Fig. 7) is difficult to explain if the age was considerably older than the $\sim 23 \mathrm{Ma}$ biotite $\mathrm{Rb}-\mathrm{Sr}$ age reported by Borsi et al. (1973) from nearby. The stepwise-heating ${ }^{40} \mathrm{Ar}-{ }^{39} \mathrm{Ar}$ results for the pseudotachylyte sample (DAV 97/16) from the Speikboden ridge are presented in Fig. 8 and the data listed in the Appendix (Table 1). Apparent ages gradually increase up to $\sim 20 \mathrm{Ma}$ during the lowest temperature steps $1-2\left(10 \%{ }^{39} \mathrm{Ar}\right)$, remain fairly flat $(17.2-21.9 \mathrm{Ma})$ for a further $\sim 80 \%$ of ${ }^{39} \mathrm{Ar}$ released and are older than $25 \mathrm{Ma}$ for the remaining high-temperature steps $12-18\left(10 \%{ }^{39} \mathrm{Ar}\right.$; Fig. $\left.8 \mathrm{a}\right)$. The associated chemical information derived from Ar isotopes shows that a distinct high $\mathrm{Cl} / \mathrm{K}$ phase gradually breaks down until step 9 , which is partially also mir- 

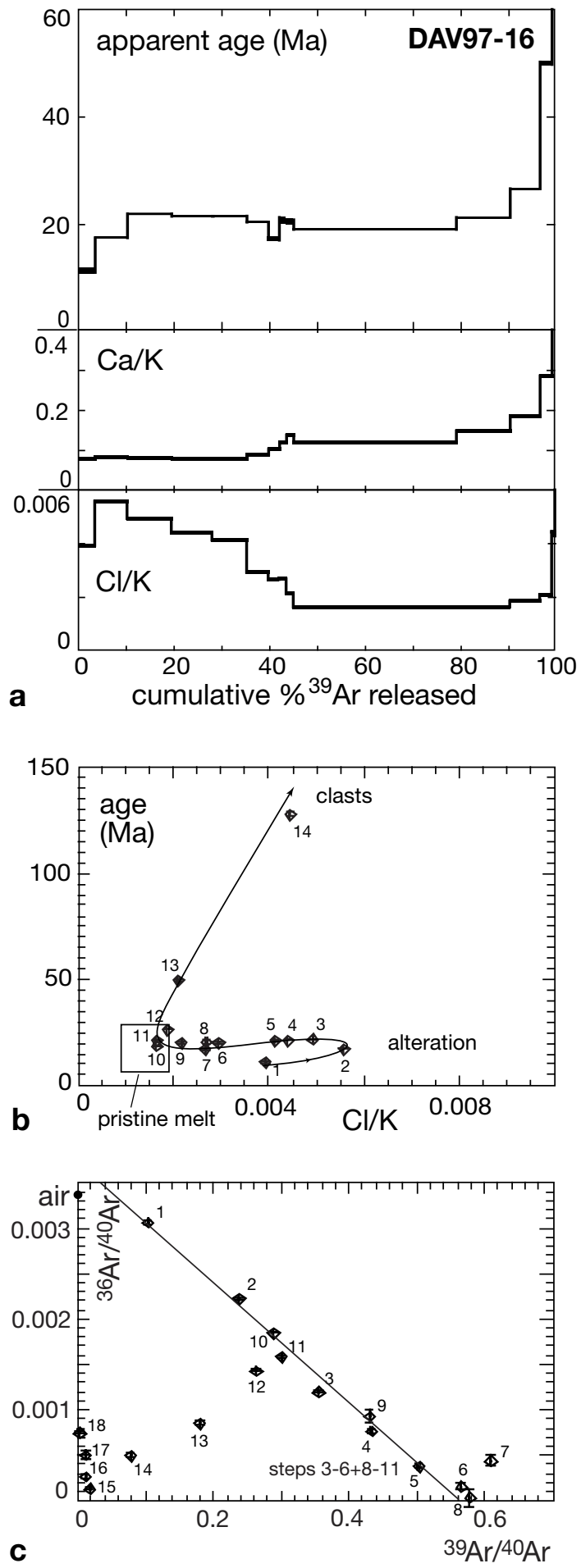

Fig. 8 a ${ }^{40} \mathrm{Ar}-{ }^{39} \mathrm{Ar}$ stepwise-heating spectra, b corresponding mineral chemical discrimination diagram based on Ar isotopes and $\mathbf{c}$ isochron diagram for pseudotachylyte DAV97/16 from Speikboden (locality L). Sample locality is on the main ridge $\sim 200 \mathrm{~m}$ ESE of the iron cross marking the Speikboden peak

rored in the corresponding $\mathrm{Ca} / \mathrm{K}$ ratios. This trend most likely reflects alteration (Fig. 8b). A second mixing trend towards clasts is shown by the high temperature steps $12-18$ (Fig. 8 b). Steps 10 and 11 at the intersection of these two trends are interpreted to most likely reflect the pristine pseudotachylyte melt

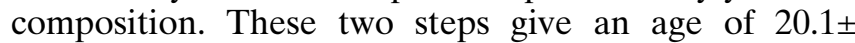
$2.2 \mathrm{Ma}(2 \sigma)$, which is identical to the age of $20.4 \pm 1.1$ (95\% c.l.) for steps $3-11\left(80 \%{ }^{39} \mathrm{Ar}\right)$. The correspond-

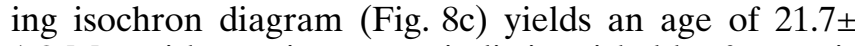
$1.8 \mathrm{Ma}$ with an intercept indistinguishable from air (270 \pm 34 ; steps $3-6,8-11)$, confirming the validity of the apparent ages considered above. These ages are totally in line with those obtained for pseudotachylytes from the Periadriatic fault discussed above, suggesting that this narrow brittle-ductile zone represents an antithetic Riedel structure to the coeval Periadriatic fault. It is also interesting to note that this age is effectively the same as the nearest zircon fission-track age of $\sim 22 \mathrm{Ma}$ from Stöckhert et al. (1999), consistent with pseudotachylyte formation at temperatures somewhat below the brittle-ductile transition in quartz-rich rocks.

\section{The DAV fault system}

\section{Introduction and previous work}

Bianchi (1934) and Dal Piaz (1934, Plate X) mapped a discrete fault with a general WSW trend from east of St. Jakob in the Defereggen valley, across the Staller Sattel (P.so di Staller) and into the Antholz (Anterselva) valley, to the south of Zinsnock (la Cima) and into the valley of Mühlbach (Valle di Riomolino), where it finished with a question mark just east of the Tauferer valley (Valle di Tures). They also delineated another tectonic boundary running approximately E-W from the Triassic lens north of Kalkstein again to the eastern side of the Tauferer valley near the mouth of the Mühlbach valley. West of there, it was continued as a dashed line to just north of Weitental (Vallarga) and then to the Triassic lens near Mauls. Borsi et al. (1973; Fig. 6) extended the trace of the first of these structures further west as far as the Vals valley and referred to it as the "Defereggen-Anterselva (Antholz)-Valles (Vals) line"; hence the usual abbreviation to DAV. The discrete line on their map was considered to be an important fault, representing the limit between a northern block with late-Alpine biotite cooling ages varying from 16 to $28 \mathrm{Ma}$ and a southern block where regional Alpine heating was not recorded. Sassi et al. (1974, 1978) and Borsi et al. (1978a) also considered the "Kalkstein-Vallarga line" (KV) to be of some importance and consequently divided the Austroalpine south of the Tauern Window into three blocks with "sharply different structural features", summarized most succinctly by Sassi et al. (1978, p 155). Borsi et al. (1978a) noted that each of the two dividing "lines" corresponds to "a main belt of cataclastic to mylonitic rocks, up to some hundred metres thick". They also pointed out that "numerous minor belts with identical geometric and structural 
features accompany the main belt" and that the lines were locally the sites of "later transcurrent movements". These two latter points can only be re-emphasized here and are the source of some difficulty in considering the DAV and KV. Firstly, although they are represented as characteristic and discrete structures on many maps, in the field it is impossible to distinguish one greenschist facies mylonite zone from another. In a region of scattered, non-continuous outcrop, as is the case here, it is not always clear that the same zone is actually being linked when distinct lines are distinguished on a sketch map. The same applies for cataclastic zones with regard to the $\mathrm{KV}$. In fact, the KV as a distinct brittle fault structure cannot be followed as far as the Tauferer valley (Schulz 1994a). Further west, a general transitional zone of enhanced cataclastic deformation is observed south of the mylonites of the DAV and a discrete $\mathrm{KV}$ is not definable (e.g. Kleinschrodt 1987).

Stöckhert (1982) divided the block north of the DAV and immediately west of the Tauferer valley into three further zones, I to III from south to north, on the basis of increasing degree of Alpine overprint. The important point here is that although the DAV is taken as the southernmost ductile Alpine overprint of quartz-rich rocks, the deformation is heterogeneous and there is an irregular gradation to increasing intensity of Alpine overprint towards the Tauern window. Stöckhert (1982, 1984, 1987) and Schulz (1988, 1989, 1994b), as representatives of a large group of students from the University of Erlangen mapping the region (Hofmann et al. 1983), distinguished between an "Old Alpine" overprint under upper greenschist facies conditions $\left(450 \pm 50^{\circ} \mathrm{C} 700 \pm 150 \mathrm{MPa}\right.$; Stöckhert 1984) and a younger overprint, showing a general transition from brittle-ductile $\left(\sim 280^{\circ} \mathrm{C}\right)$ at the DAV itself to increasing greenschist facies to the north (Stöckhert et al. 1999). The distinction was made on the basis of metamorphic conditions during deformation, without discussion of the possible kinematics of the older event. In particular, recrystallization of both plagioclase and $\mathrm{K}$-feldspar in mylonitized pegmatites and the development of annealed quartz microstructures were considered characteristic of the older phase (e.g. Stöckhert 1982, 1987), whereas feldspar was only brittle and quartz preserved dynamic microstructures and (partially) recrystallized to a much finer grain size in the younger event (Kleinschrodt 1987; Stöckhert et al. 1999). Stöckhert (1984) established that both the coarse- and fine-grained white mica fractions of deformed pegmatites near Uttenheim gave concordant Cretaceous $\mathrm{K}-\mathrm{Ar}$ ages ( 100 Ma), similar to ages obtained previously by Borsi et al. (1973) in pegmatites from further west, near Weitental. These results were used to distinguish two events: the Cretaceous "Old Alpine" or "Eoalpine" event and the Tertiary DAV; however, as discussed below, we do not find such a clear distinction in microstructure. In several of the classic locations for DAV mylonites (e.g.
Mühlbach, Talson, west of Weitental) feldspar deforms crystal-plastically and recrystallizes by subgrain rotation, and there is a retrograde transition from preserved higher-grade dynamic microstructures to lower-grade microstructures, often in the same thin section.

Kleinschrodt (1987) undertook a systematic study of the deformation microstructure of quartz-rich rocks in the Austroalpine south of the Tauern window, in a broad profile west of the Tauferer valley. He distinguished two zones of particularly intense Alpine greenschist-facies deformation: along the DAV itself and the "Speikboden mylonites" in the northern zone III of Stöckhert (1982), across the boundary to the Tauern window. A critical observation, discussed later, is that the deformation fabrics and metamorphism are continuous across the boundary to the Tauern window, as already established by Nollau (1969). The maximum age of the shared deformation fabric at the contact therefore provides a time limit on relative overthrusting of the Austroalpine over the Penninic units. Stöckhert $(1982,1984)$ considered the common fabric to be at least in part of Cretaceous age, which would also be consistent with published models of early Cretaceous subduction of the Penninic Glockner nappe units under the Austroalpine (e.g. Frisch 1984; Frisch et al. 1987). However, as discussed below for the Vals-Ochsensprung section, Oligocene dykes within the Tauern window close to the boundary also show clear evidence for sinistral strike-slip overprint, and it is not clear how much of the common sinistral fabric across the boundary is of Tertiary age. This highlights the general problem of distinguishing "Old Alpine" from younger fabrics. Kleinschrodt (1987) was the first to clearly establish that movement on DAV-related mylonite zones was consistently sinistral, with a minor north-side-up component. He also established a relationship between the dynamic microstructure of quartz and the gradient in Alpine metamorphic temperature across the DAV. This work was extended by Stöckhert et al. (1999), using new zircon fissiontrack results to better constrain the gradient in temperature.

The age, or better, range of ages associated with movement on the DAV mylonites is still equivocal and to some extent also reflects the problem of defining the "DAV mylonites" in the first place. It was already well established from the studies of Dal Piaz (1934) and Bianchi (1934) that the irregular contact of the Rieserferner pluton crosscuts the foliation and banding in the country rock and is not affected by any younger pervasive ductile overprint. The heterogeneous but locally intense ductile shearing north of the DAV "line" must be older than pluton emplacement. The question then arises as to whether all these regionally widespread mylonite zones are Cretaceous "Old Alpine" structures and only the mylonites and cataclasites bound to the DAV "line" itself, running immediately south of the Zinsnock pluton, are 
younger than the intrusion, as implied by Stöckhert (1982) and Schulz (1989, 1994a, 1994b). Mager (1985), working in the southern Rieserferner and Zinsnock region, established that some dykes were mylonitized by the DAV and contact metamorphosed in the main aureole, whereas the main pluton and later dykes lack such a pervasive solid-state overprint. We are in complete agreement with these observations, as discussed in detail below. In combination with the discussion of Periadriatic fault kinematics presented above, it follows that there was an important and abrupt change in regional kinematics coeval with intrusion of the major Periadriatic plutons. A series of locations, from east to west (Fig. 1), are now discussed to establish the important characteristics of heterogeneous Alpine sinistral shearing (in the current orientation) south of the Tauern window.

\section{Stemmeringer Almbach}

The Stemmeringer Almbach section (location A, Fig. 1) was previously described by Schulz (1988, Fig. 7.3, 1989, Fig. 3B). A sketch map of locations and field relationships is given in Fig. 9. The locality provides some of the best samples for considering the relationship between intrusion of the Rieserferner pluton, contact metamorphism and mylonitization. The country rock consists of mica schist and paragneiss, with subordinate marble and vein quartz, intruded by aplite, lamprophyre and tonalite dykes and the main Rieserferner tonalite pluton. Over a distance of $\sim 200 \mathrm{~m}$ away from the pluton contact to the southwest, there is a gradient in the deformation fabric from moderately foliated, contact metamorphic schists into strongly foliated mylonites and finally an increasingly colder and eventually cataclastic overprint (see Fig. 9 and the schematic profile, Fig. 3B, of Schulz 1989). In the higher-strain ductile zone, aplite and tonalite dykes are mylonitized together with the country rock, with the same sinistral kinematics and under the same metamorphic conditions (e.g. at location 2 in Fig. 9). Andalusite porphyroblasts related to contact metamorphism are partly transformed to white mica and synkinematically deformed again with the same sinistral shear sense (location 3, Fig. 9; Fig. 10a). $\mathrm{Rb}-\mathrm{Sr}$ microchrons of white mica-andalusite pairs give an age of $30.1 \pm 4.6 \mathrm{Ma}$ (sample DAV9; Müller et al. 2000), within error limits the same as the published $\mathrm{Rb}-\mathrm{Sr}$ whole-rock age for the Rieserferner pluton (31 $\pm 3 \mathrm{Ma}$, recalculated after Borsi et al. 1978b). The pluton rim is itself foliated, but without a clear lineation. Most importantly, at location 1 in Fig. 9, it was possible to sample across the intrusive contact into an adjacent narrow $(<1 \mathrm{~m})$ foliated zone of country rock with a well-defined shallow lineation. The shear sense associated with the solid-state deformation microstructure in both tonalite and country rock is here clearly dextral (Fig. 10b). At least locally, there is therefore a

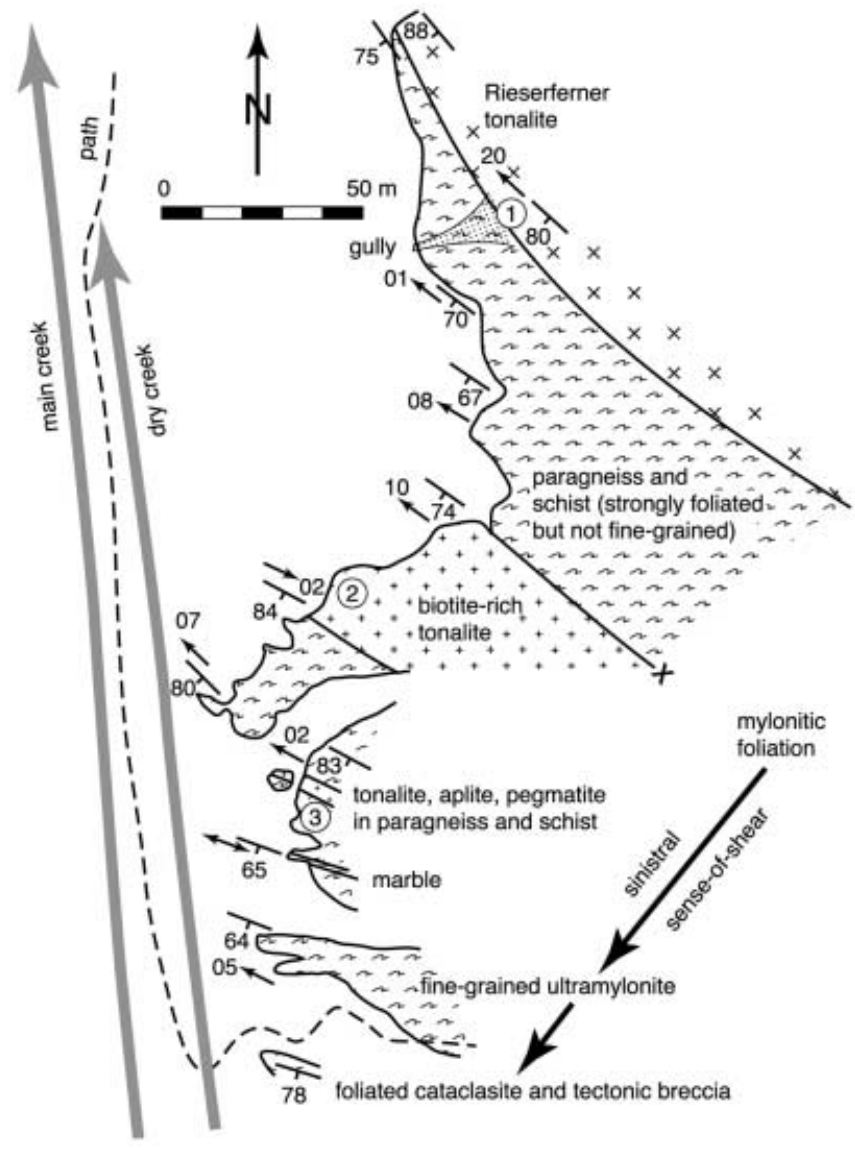

Fig. 9 Sketch map of the Stemmeringer Almbach locality (A in Fig. 1)

change in kinematics from sinistral to dextral between intrusion of the precursor dykes (which are not found within the pluton itself), the growth of contact metamorphic andalusite, and the final solidification of the main pluton at its current level. NW-SE or E-W striking brittle dextral strike-slip faults and brittle topto-SE reverse faults consistent with Periadriatic fault kinematics (see the relevant section above) crosscut the main Rieserferner intrusion. The field observations therefore document a change from sinistral DAV to dextral Periadriatic kinematics during intrusion and final solidification of the main Rieserferner pluton (Schulz 1989).

\section{Staller Sattel}

The Staller Sattel section (location C, Fig. 1) occurs along the Austrian-Italian border, to the north of the road from the Antholz valley to the Defereggen valley. It was described in detail by Schulz, and his schematic profile (Fig. 3a in Schulz 1989) and map (Fig. 1 in Schulz 1994b) form a good basis for discussion. Several observations along the Staller Sattel section are important for establishing regional DAV relationships. 

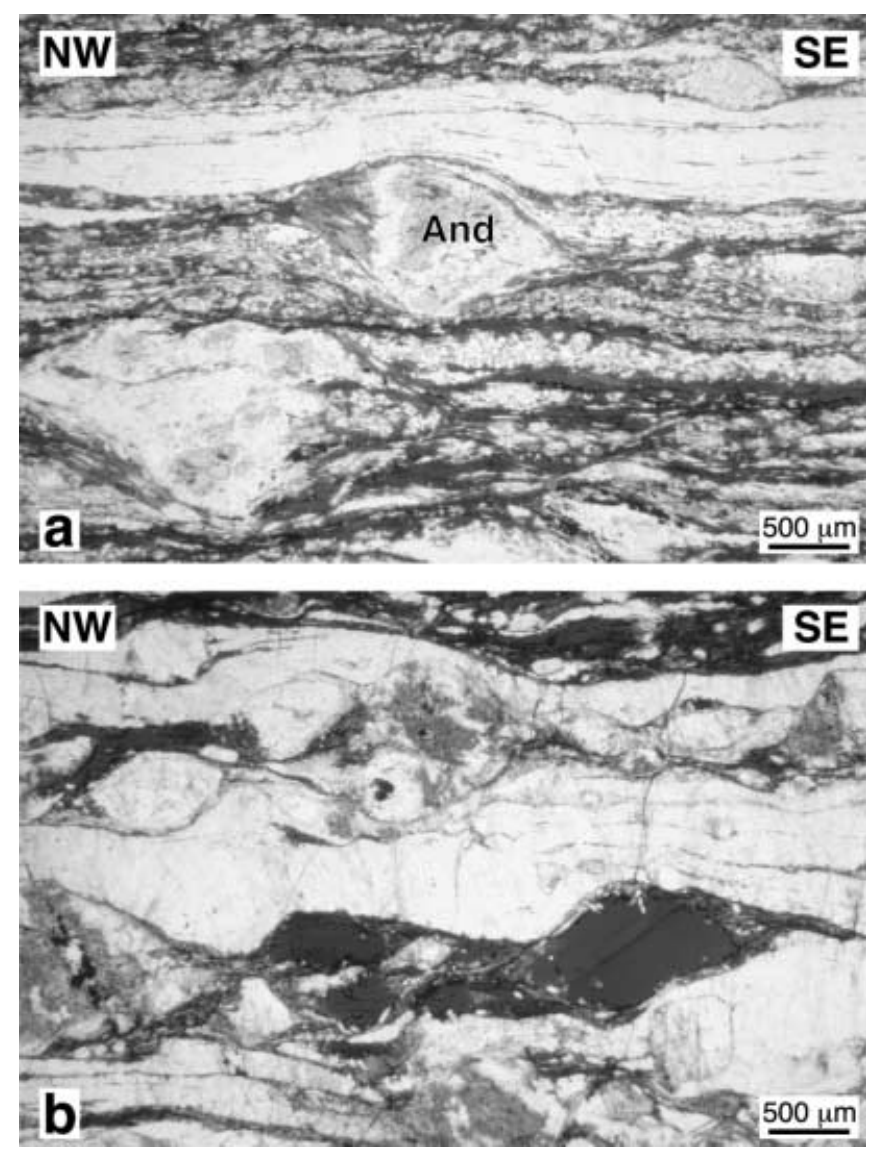

Fig. 10 a Sigmoidal andalusite porphyroclasts (And), indicating sinistral shearing, with new biotite and muscovite growth in the pressure shadows (location 3, Fig. 9). Foliation 204/70, lineation 295/03. Dominant shear bands, with stable biotite, are sinistral, but there are also rare, discrete "colder" dextral shear bands and faults. b Dextral shearing of tonalite within $1 \mathrm{~cm}$ of the intrusive contact (location 1, Fig. 9). Foliation 222/80, lineation $313 / 20$

Firstly, a penetrative overprint of the pre-Alpine gneisses already occurs in a band immediately south of the main cataclasite zone. In the field, the well-developed planar foliation is parallel to the main cataclasite zone and contains a clear lineation pitching moderately SE. The rock has characteristic knots of chlorite randomly distributed on the foliation surface. This is the unit referred to as the "green fine-grained feldspar-quartzite-gneiss" of Schulz (unit 2 in Fig. 3a in Schulz 1989). In thin section, the main foliation is defined by well-aligned chlorite, both feldspar and quartz deform crystal-plastically, feldspar recyrstallizes by subgrain rotation and quartz by grain-boundary migration, with coarse quartz ribbons, sometimes developed across the width of a thin section. The age of this fabric is unknown. As described by Schulz (1989), this strongly foliated rock is followed to the north by foliated black cataclasites transitional over a distance of $30-50 \mathrm{~m}$ into fine-grained mylonites. The whole zone is very friable and difficult to sample. No consistent lineation or associated sense of movement could be established in the cataclasites, but the more compact mylonites show a horizontal or shallow westplunging lineation. In the middle of the fine-grained friable mylonite zone, there is an outcrop of a pale greenish rock with characteristic millimetre-sized muscovite and white feldspar porphyroclasts, which in field appearance is identical to group-1 Oligocene dykes, such as the dated sample JP102 from the Sterzing area discussed below (Fig. 3b). In thin section the dyke has a mylonitic foliation wrapping around magmatic plagioclase (partly recrystallized by subgrain rotation) and muscovite phenocrysts (Fig. 11a). The sense of shear is sinistral, relative to a nearly horizontal lineation. Synkinematic sericitization is marked, similar to that observed around contact metamorphic andalusite at the Stemmeringer Almbach location. A mylonitic marble band (unit 9 in Fig. 3a in Schulz 1989 ) is transitional to more compact quartz-rich micaceous mylonites to the north (the phyllonite unit 10 in Fig. 3a in Schulz 1989). The sense of shear in all these mylonites is clearly sinistral and, most importantly, feldspar recrystallizes (Fig. 11b, c) and biotite is a stable mineral, together with chlorite, during shearing both in the main foliation and in the common shear bands. From here to the north, there is a general coarsening in grain size and the mylonitic overprint is less pervasive. In places, weakly overprinted Permian pegmatites crosscutting older pre-Alpine fabrics are preserved; however, in distinct shear zones on the scale of metres to tens of metres, the pegmatites are also locally very intensely sheared. The foliation and lineation orientation and the sense of shear in these zones are identical to those in the mylonite zone considered to represent the DAV. In thin section (Fig. 11d), alternating bands of recrystallized quartz and feldspar are developed. The quartz is coarse grained and recrystallized by grain-boundary migration and exaggerated grain growth, and the feldspar has fully recrystallized with consequent grain-size refinement. Quartz still preserves a dynamic microstructure, with irregular lobate grain boundaries, and is not annealed to develop low-energy straight boundaries and triple points (Fig. 11d). These high strain zones strike into the Rieserferner pluton and are transected by the contact. They must therefore precede pluton emplacement. Locally, contact metamorphic andalusite porphyroblasts overgrow strongly planar foliated units, in which the foliation is considered equivalent to the Alpine foliation of Fig. 11d (e.g. Schulz 1994b, Fig. 20c).

The recognition of three different alpine foliations with associated differences in metamorphic grade by Schulz (1994b) cannot be reconciled with our own observations. Feldspar recrystallizes in the fine-grained mylonites of the classic DAV zone, in the Oligocene dyke overprinted within this zone, and more extensively, in the mylonitic pegmatites further north. Biotite is stable throughout, although deformation has continued on a retrograde path towards predominantly 

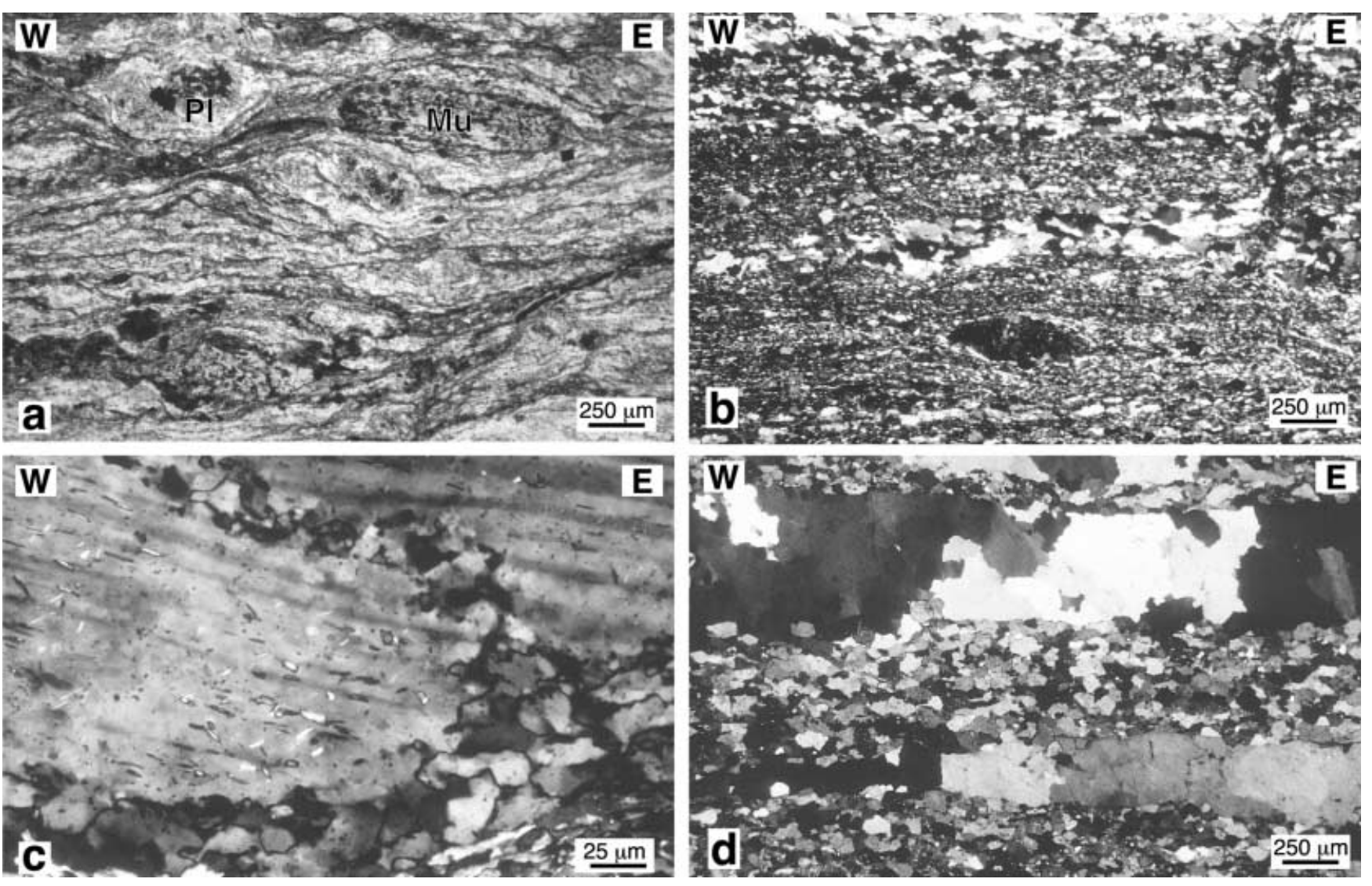

Fig. 11 Microstructures from the Staller Sattel section (location C, Fig. 1). a Sinistral mylonitization (indicated by shear bands, sigmoidal clasts and oblique quartz fabrics) in the greenish-grey dyke (location 6 in Fig. 3a; Schulz 1989) with zoned plagioclase feldspar $(\mathrm{Pl})$ and muscovite $(\mathrm{Mu})$ phenocrysts identical in appearance to the $\sim 30$ Ma samples BG 169 and JP102 from further west, dated by Müller et al. (2000). Feldspar partially recrystallizes and biotite is stable. Foliation 334/65, lineation 244/01. b Immediately adjacent mylonites of the classic DAV, showing coarser-grained quartz and finer-grained plagioclase recrystallization. Sinistral sense of shear clear from sigmoidal, partially recrystallized feldspar clast and the oblique quartz fabric. Foliation and lineation orientations are the same as in a. $\mathbf{c}$ Close-up of plagioclase recrystallization by subgrain rotation from the same sample as in b. d Mylonitic (Permian) pegmatite from $\sim 600 \mathrm{~m}$ further NNE, developing alternating finer-grained recrystallized feldspar and coarser-grained quartz ribbons. Foliation 332/64, lineation 246/10. Sense of shear is sinistral from oblique quartz fabrics. Note the increase in recrystallized grain size consistent with a coeval temperature gradient to the north. The dynamic microstructure is preserved, with very irregular lobate quartz grain boundaries typical of grain-boundary migration and no sign of subsequent static annealing

chlorite growth and eventually brittle fracture. The same fabric appears to be gradational to higher grade to the north. It cannot be directly established whether the irregularly developed high-grade mylonite zones overprinting the pegmatites are coeval with the DAV mylonites, although their orientation and kinematics are identical. This is not, admittedly, a sufficient argument for coeval development since, as discussed in

general above, there is ample evidence for continued reactivation of fault zones over extended periods.

\section{Zinsnock}

The Zinsnock area (location D, Fig. 1) was discussed by Mager (1985) and we are in general agreement with his observations. In particular, it is clear that the mylonites generally assigned to the DAV are clearly transected and metamorphosed by the Zinsnock pluton. Internally the pluton itself shows little evidence for pervasive ductile solid-state deformation (Fig. 12a). According to Mager (1985), early tonalitic dykes (group 1 introduced above), which are not observed in the main pluton itself, are locally mylonitized and subsequently contact metamorphosed. There is also evidence for local minor sinistral shearing of andalusite porphyroblasts developed in the contact aureole during sericitization, similar to the relationships discussed for the Stemmeringer Almbach. This is important because it demonstrates that at least a component of sinistral shearing continued up until the time of main pluton emplacement. The mylonites of the DAV are bordered to the south by a zone of black cataclasite tens of metres wide. In the mylonites immediately adjacent, pseudotachylytes are common both transecting the mylonite fabric and foliation parallel. One generally foliation-parallel but locally discordant pseudotachylyte (Fig. 12b, DAV 97/2) was 

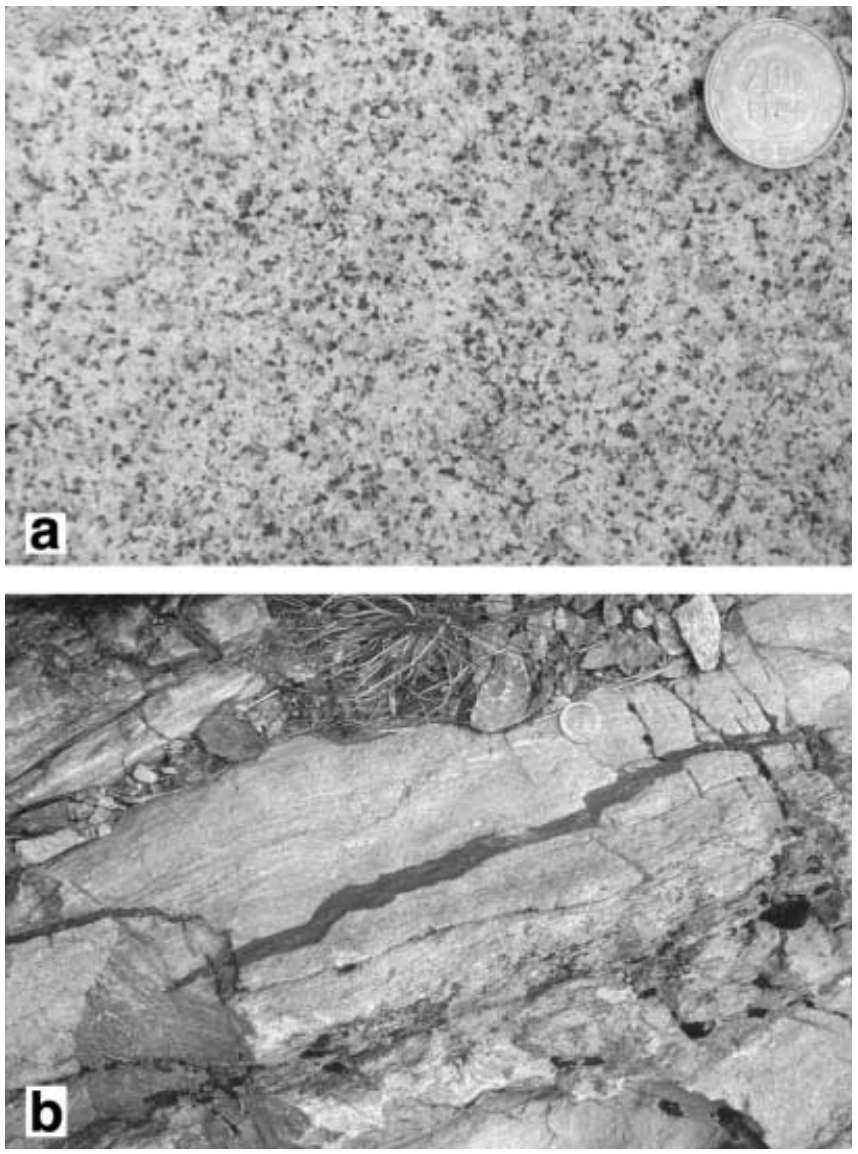

Fig. 12 a Undeformed Zinsnock tonalite that crosscuts the strongly foliated DAV mylonites in the adjacent contact aureole. In thin section, solid-state deformation is limited to undulose extinction and minor subgrain formation in quartz. b Pseudotachylyte generally concordant but locally crosscutting the DAV mylonitic foliation. Foliation 180/54, lineation 120/33. As noted in text, the lineation is typically steeper in the southernmost DAV mylonite exposures. The pseudotachylyte was sampled as DAV97/2 for Ar-Ar dating (see Fig. 13)

selected for ${ }^{40} \mathrm{Ar}-{ }^{39} \mathrm{Ar}$ dating and the results are tabulated in the Appendix (Table 2). The corresponding apparent age spectrum (Fig. 13a) shows a staircase increase of ages from 5 to 45 Ma during the low-temperature steps and then forms a flat spectrum for the next $\sim 75 \%{ }^{39} \mathrm{Ar}$ released. The highest temperature steps are characterized by first a slight drop and then a subsequent increase in ages. The associated chemical information from $\mathrm{Ar}$ isotopes shows high $\mathrm{Cl} / \mathrm{K}$ ratios during the first three steps indicative of alteration phases. High $\mathrm{Cl} / \mathrm{K}$ and $\mathrm{Ca} / \mathrm{K}$ ratios during the highest experiment temperatures most likely indicate surviving clasts of the precursor rock. Steps 4-11 have a virtually identical chemical composition and are interpreted as reflecting the pristine pseudotachylyte matrix (melt) composition. An age of $46.1 \pm 3.1 \mathrm{Ma}$ (95\% c.l.) can be calculated from steps $9-11 \quad(65 \%$ 39Ar). Although chemically similar, steps 4-8 show increasing ages from 20 to $40 \mathrm{Ma}\left(14 \%{ }^{39} \mathrm{Ar}\right)$. This
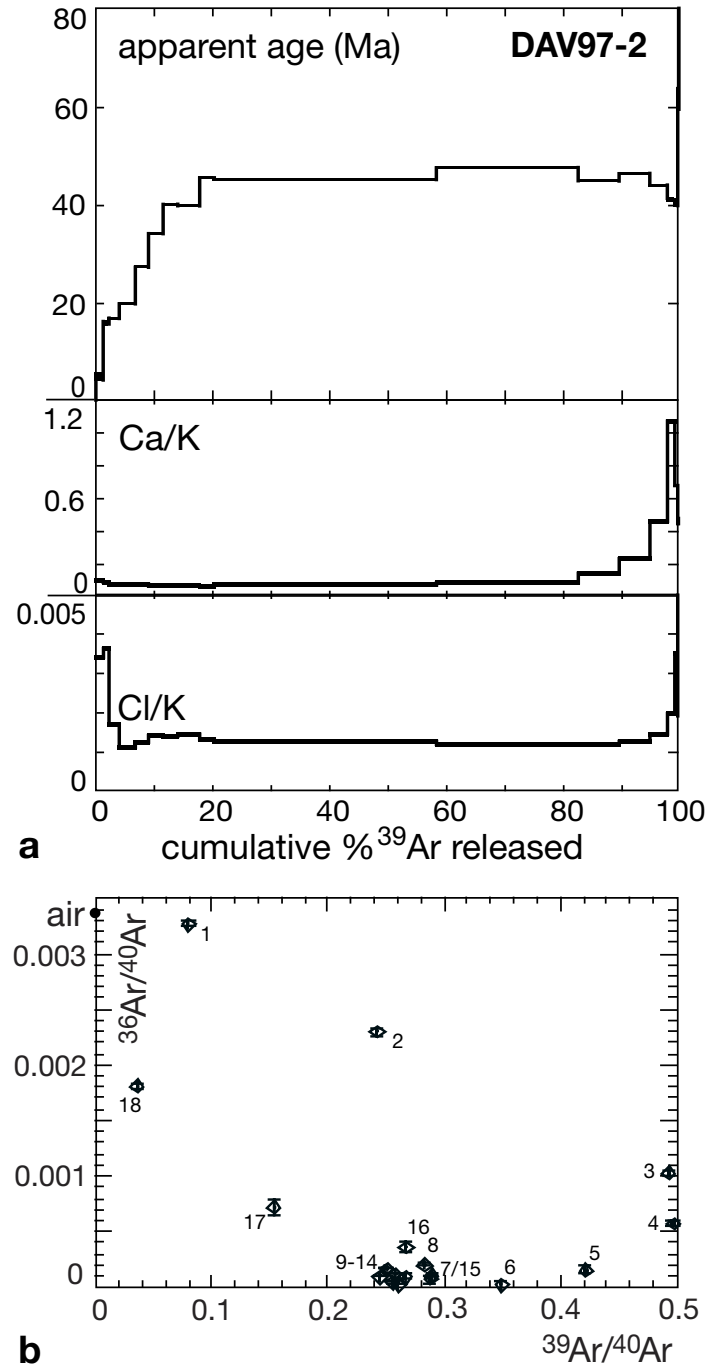

Fig. 13 a ${ }^{40} \mathrm{Ar}-{ }^{39} \mathrm{Ar}$ stepwise-heating spectra, and b isochron diagram for pseudotachylyte DAV97/2 from Zinsnock (locality D). Located in the narrow gully above Haidacher Alm, at $2045 \mathrm{~m}$ altitude, $850 \mathrm{~m}$ SE of Zinsnock peak (see Fig. 12b)

may reflect rejuvenation due to the neighbouring Zinsnock intrusion ( $31 \mathrm{Ma})$ and/or fluid-induced alteration during Neogene brittle reactivation, as indicated by brittle faults in the same outcrop (Fig. 6). When plotted on an isochron diagram (Fig. 13b), steps 9-11 (among others) plot on or very close to the ${ }^{39} \mathrm{Ar} /$ ${ }^{40} \mathrm{Ar}$ axis, therefore minimizing possible contributions from inherited and/or excess Ar components, which could produce a false (and older) apparent age.

If this interpreted age of $46 \mathrm{Ma}$ is correct, it establishes that the transition to co-seismic brittle deformation had locally already occurred in the Eocene. This result is identical to zircon fission-track ages reported by Stöckhert et al. (1999) from directly along the strike to the west of the Tauferer valley (see dashed line in Fig. 1 and discussion below). The age is also clearly consistent with the mylonite belt being 
crosscut by the Oligocene Zinsnock pluton; however, the overprint of dykes and (locally) of contact metamorphic minerals demonstrates a reactivation with sinistral strike-slip kinematics during the mid-Oligocene. Excellent stepped fibres on minor fault surfaces near the transition to the cataclasite zone demonstrate a further reactivation with dextral plus north-side-up kinematics (Fig. 6), consistent with the later Periadriatic fault movements. Similar to Staller Sattel (and Weitental below), there is a zone of strongly planar foliated micaceous schist and gneiss immediately south of, and parallel to, the cataclasite zone with typical elongate quartz ribbons, in which coarse-grained quartz is dynamically recrystallizing by grain-boundary migration. The age and kinematics of this zone is not established.

\section{Hochhorn}

To the north of the Zinsnock pluton, this well-exposed section (location E, Fig. 1) runs along the west side of the ridge immediately north of the Hochhorn (Corno Alto). The section is particularly important for establishing a relative sequence of Alpine vs pre-Alpine deformation events on the basis of clear geometric relationships. The strain is spatially heterogeneous, with pre-Alpine fabrics often well preserved (Cesare 1999), as is established where little-deformed late-Hercynian pegmatites crosscut the pre-Alpine fabric. However, this pre-Alpine fabric is also effectively parallel to mylonitic shear zones, with widths on the scale of metres to tens of metres that overprint the pegmatites. Distinguishing Alpine from pre-Alpine fabrics on the basis of orientation alone is therefore not possible. In the mylonite zones, both feldspar and quartz recrystallize, by subgrain rotation and grain-boundary migration, respectively, to develop bands of alternating finegrained feldspar and coarse-grained quartz. The dynamic grain-boundary microstructure of quartz and feldspar is still preserved and there is no evidence for extensive annealing to develop straight boundaries and triple-point geometries. Older garnet porphyroclasts are partly transformed to biotite, often as asymmetrical pressure shadows indicating sinistral sense of shear. Sigmoidal garnet and feldspar porphyroclasts, biotite-filled shear bands, and oblique grain-shape fabrics of quartz also indicate a consistent sinistral shear sense relative to a lineation that plunges shallowly west to southwest on a generally steeply dipping foliation. This mylonitic foliation is folded around fairly open folds without a penetrative axial plane foliation, with axes that plunge shallowly to the east. The vergence of these asymmetrical folds indicates an antiform to the north. In thin section it is seen that new biotite grows parallel to the axial plane of these folds, and that the contact metamorphic andalusite porphyroblasts overgrow both the mylonitic fabric and the fold hinges. Dykes related to the Rieserferner intru- sion crosscut the folds. On a larger scale, these folds are almost certainly parasitic to the large antiform developed in the region of the Rieserferner pluton itself (Fig. 1; Dal Piaz 1934; Agterberg 1961; Henry 1975; Mager 1985), which is itself crosscut by the main intrusion (e.g. Dal Piaz 1934). The randomly oriented andalusites of the contact aureole are weakly deformed, developing undulose extinction and locally subgrains, as well as fractures that are filled with (often fibrous and oriented) muscovite and fibrolite. This again provides evidence for continued deformation during prograde contact aureole formation, but no examples of deformation approaching the intensity of the Stemmeringer Almbach section were found. Unfortunately, there is little absolute time control on the formation of the mylonites other than they are younger than the (almost certainly Permian) pegmatites and older than the Zinsnock and Rieserferner plutons (31 $\pm 3 \mathrm{Ma}$; Borsi et al. 1978b).

Northern contact to the Rieserferner pluton near Sand in Taufers

This section (location K, Fig. 1), which obliquely transects the northern contact of the Rieserferner pluton, can be followed along the path from above Ahornach (east of Sand in Taufers) to Kofler, and confirms several previous observations. The tonalite itself is weakly foliated, defined by a preferred orientation of biotite and amphibole crystals, but without a clear lineation. However, there is no evidence of significant solid-state deformation and the pluton and related aplitic and pegmatitic dykes crosscut the well-developed foliation in the adjacent paragneisses and schists. Large, randomly oriented white mica grains and radiating fibrolitic sillimanite are common in more pelitic units at the immediate contact. Shearbands in the country rock are consistent with a sinistral strike-slip sense related to the shallow-plunging lineation. At one location $\left(\mathrm{N} 46^{\circ}\right.$ 55.34', E12 ${ }^{\circ}$ 00.04', $530 \mathrm{~m}$ direction $260^{\circ}$ from Kofler), a greenish-grey foliated group-1 dyke crosscuts the main fabric but is itself internally foliated, parallel to the dyke walls. Folds in the main country-rock foliation, similar to those described above from near Hochhorn, are also observed with axial planes dipping $\sim 60^{\circ}$ to the $\mathrm{NW}$, fold axes plunging $\sim 20^{\circ}$ towards $\mathrm{NE}$, and vergence antiform to the north. The fold asymmetry indicates that the major structure between here and Hochhorn is a regionalscale antiform-synform pair, with the same vergence as the outcrop-scale folds (i.e. indicating an antiform towards the Tauern window; see Fig. 1).

\section{Mühlbach-Uttenheim}

Now we consider the critical and controversial area between Mühlbach and Uttenheim (Tauferer Valley, 

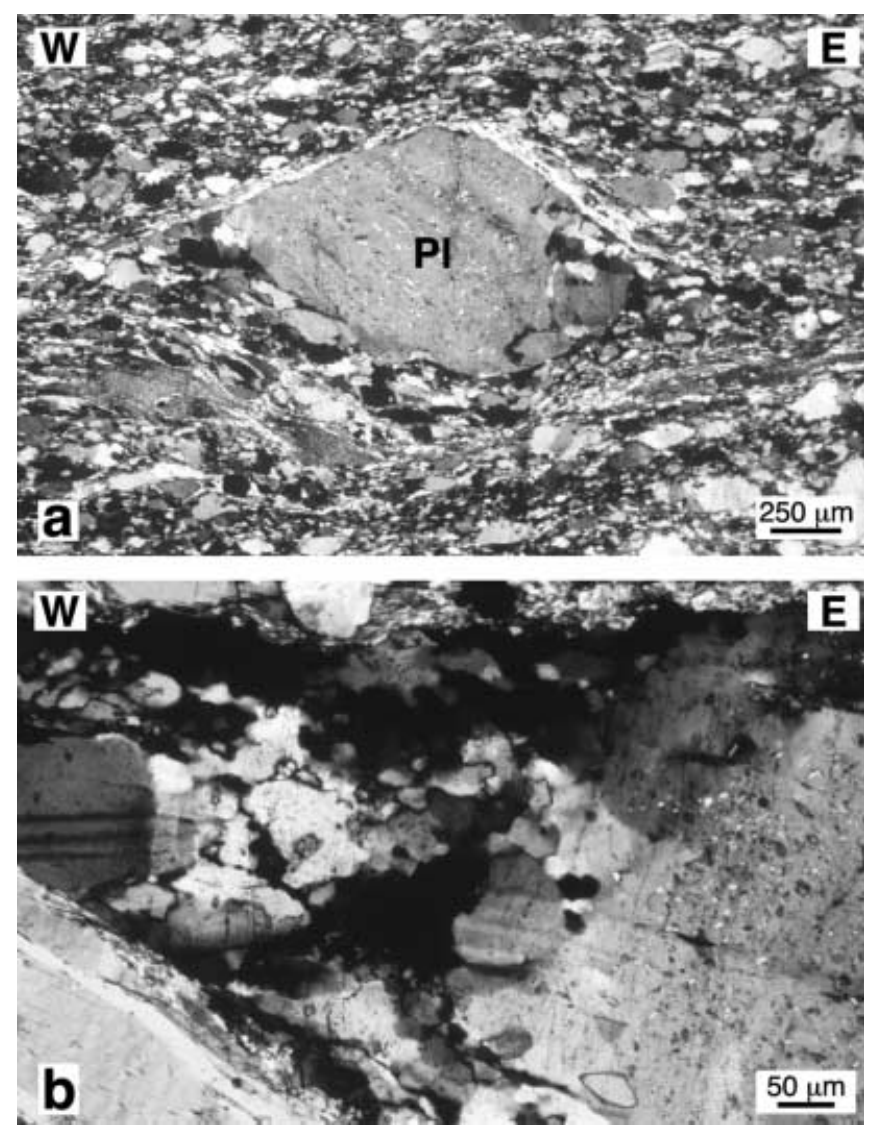

Fig. 14a, b DAV mylonites at Mühlbach (locality F, Fig. 1). a Plagioclase sigma-clast $(P l)$, showing crystal plastic deformation and incipient recrystallization, in a (sinistral) mylonitic orthogneiss. The foliation is defined by bands of extensively recrystallized quartz and feldspar. Foliation 177/70, lineation 081/02. b Enlargement from an adjacent sample, showing recrystallization of plagioclase by progressive subgrain rotation

locations F-I, Fig. 1). The Mühlbach locality (location $F$ in Fig. 1) represents the westernmost outcrop to which the DAV was traced with some certainty in the original work of Dal Piaz (1934), but unfortunately this area is not well exposed. It is certainly true that there is a strong mylonitic foliation and lineation developed (foliation dipping $\sim 70^{\circ}$ to the $\mathrm{S}$, lineation practically horizontal), that the outcrop is more or less on line with the Zinsnock exposure discussed above, and that to the south the orthogneiss is overprinted by cataclastic faults and joints. As is clear from Fig. 14, the mylonites were developed under conditions conducive to feldspar recrystallization, similar to those discussed from the Hochhorn and Staller Sattel sections. Dal Piaz (1934) was uncertain as to the continuity over the Tauferer Valley, an opinion reiterated by Nollau (1974, p 77). Borsi et al. (1973) extended it further west as a boundary between Alpine and preAlpine biotite ages, but the field expression was not well defined and its exact location tended to vary in subsequent papers from author to author. Based on structural and lithological arguments, Stöckhert (1982) considered that the true location of the DAV west of the Tauferer valley lay considerably further north, near Uttenheim (Fig. 1). He assigned the zone of more cataclastic deformation on the west side of the Tauferer valley, directly on line from the Mühlbach outcrop, to the KV rather than the DAV. If the DAV is to be taken as a single continuous structure, this requires a N-S or NNE/SSW-trending dextral fault with an offset of ca. $2 \mathrm{~km}$, as was subsequently proposed on the (sketch) maps of, for example, Stöckhert (1984, 1987), Schulz (1994a) and Stöckhert et al. (1999). Outcrop conditions do not allow any real field control, however, and our observations indicate that faults from the general region with a NNE-SSW trend consistently show a sinistral sense, similar to the Passeier-Giudicarie fault system (Fig. 5).

As noted previously, Stöckhert (1982) and subsequent workers from the Erlangen group considered the DAV to continue west of the Tauferer valley from immediately south of Uttenheim towards and across the Sambock ridge (e.g. Hofmann et al. 1983). A wellexposed and easily accessible section on the west side of the valley occurs along path 17 from Lärchner to the south. Outcrops of strongly foliated rocks start where the path crosses the Kressbrunntal at $1536 \mathrm{~m}$ elevation and continue in a gradation to less overprinted, more coarse-grained pre-Alpine migmatites near Lärchner itself, over a distance of $\sim 200 \mathrm{~m}$ to the NE (location G, Fig. 1). Directly along strike on the eastern side of the Tauferer valley, a very similar section of mylonites is found in scattered hill exposures above the road from Uttenheim to Mühlbach, starting approximately $100 \mathrm{~m} \mathrm{SE}$ of Lana and extending for 150-200 $\mathrm{m}$ further south (location H, Fig. 1). The sense of shear is sinistral (when steeply dipping) or top to east (when more shallowly dipping, since the foliation is broadly folded; see below), as established from asymmetrical shear bands. Initial deformation conditions produced grain-boundary migration and grain coarsening in quartz and advanced feldspar recrystallization. Both biotite and chlorite are stable in pressure shadows around garnet and in shear bands, with chlorite dominating in shear bands, suggesting a retrograde history. Quartz fabrics are not annealed but show strong undulose extinction and preserved subgrains, also indicative of deformation under decreasing metamorphic grade. The mylonites are openly folded around axes plunging $10-15^{\circ}$ ENE, parallel to the stretching lineation, with axial planes dipping $\sim 60^{\circ}$ to the north. Related to this folding, the broad mylonite band shallows to the north into an antiformal hinge. In this broad hinge zone (location I, Fig. 1), the foliation dips $5-15^{\circ}$ to the $\mathrm{E}$ or SE, with the same stretching lineation, microstructure and sense of shear (now top to E) as before. At least one narrow (ultra-) mylonitic shear zone ( $5 \mathrm{~m}$ wide), similar in field aspect, orientation, microstructure and kinematics to those described for the Hochhorn locality, 
occurs $400 \mathrm{~m}$ southeast of the broad mylonite band (location $\mathrm{J}, \mathrm{N} 46^{\circ} 51.83^{\prime}, \mathrm{E} 11^{\circ} 58.48^{\prime}$ ). If the $200-\mathrm{m}$ wide mylonite zones described here to either side of Tauferer valley are correlatable, then there is no major fault structure running along the valley. The two mylonite zones correlated as the DAV in previously published sketch maps (see, for example, Stöckhert et al. 1999; Fig. 1) must therefore be different parallel zones with similar kinematics and deformation microstructures.

\section{Talson}

Outcrop conditions at Talson are generally poor, but a band of well-developed mylonites is exposed where the road from Terenten to Talson crosses the Talson creek (location M, Fig. 1), whereas to the south several metre-wide shear zones (foliation dipping $\sim 60^{\circ}$ to the $\mathrm{N}$, lineation almost horizontal E-W) occur sporadically in the generally pre-Alpine (and in part migmatitic) gneiss fabric. The mylonites of the main band at the Talson creek crossing are fine grained and look low-grade in outcrop. Quartz deformation is extreme, with very elongate ribbons. Recrystallization is advanced and exclusively by subgrain rotation leading to grain-size reduction. Undulose extinction and checkerboard patterns in the old quartz grains also indicate relatively high stress (i.e. relatively low temperature or high strain rate) and little sign of annealing; however, there is also clear evidence for subgrain rotation recrystallization of plagioclase.

The mylonitic foliation is somewhat differently oriented from the regional trend, dipping moderately to steeply to the NW, with the lineation near horizontal and NE-SW. From the linear trend of the deeply incised creek, the along-strike regional shear-band-like swing in the mappable units (Hofmann et al. 1983), and the apparent offset in the small Oligocene intrusions (Fig. 1), it is attractive to interpolate a sinistral antithetic Riedel shear to the Periadriatic fault at this location, which may find its continuation in the very fine-grained mylonites and $20-\mathrm{Ma}$ pseudotachylytes from Speikboden described previously (Fig. 1). An antithetic Riedel fault here could also accommodate deformation in the northern block provoked by the marked change in orientation of the Periadriatic fault at the point of intersection of the proposed Riedel with the Periadriatic fault (Fig. 1). Although the limited outcrop conditions hamper any definitive answer, this may be another example, like Speikboden, where younger sinistral antithetic Periadriatic Riedel shearing overprints a previous higher temperature sinistral fabric, and where the two effects are not easy to separate unequivocally.

\section{Weitental}

The road west from Weitental (location N, Fig. 1) to Meransen, together with the forestry road continuing further north from the northernmost bend in the asphalt road (1.2 km NW of Weitental), provides an excellent section through the sinistral mylonite zone traditionally assigned to the DAV. Here, the mylonite zone apparently extends to the south as far as the Periadriatic fault, although the last tens of metres are not exposed. The foliation in general dips moderately $\left(30-50^{\circ}\right)$ to the $\mathrm{N}$ or $\mathrm{NW}$ and the lineation is near horizontal or plunges very gently $\mathrm{E}$ to NE. The plunge angle of the lineation is on average higher in the south of the section, near the Periadriatic fault (plunging $25-50^{\circ} \mathrm{NE}$ ). The sense of shear is consistently sinistral (plus north side up). In the south, brittle sinistral Riedel faults are transitional to shear bands. Between the discrete Riedels, the mylonitic foliation is rotated in a clockwise sense, resulting in local NW-SE foliation strike, but the average strike of the foliation and banding is still E-W to ENE-WSW, and therefore obliquely transected by the more E/W to ESE/WNWtrending Periadriatic fault (Fig. 1). Even in the southernmost samples with the clear brittle overprint, biotite and amphibole were still stable and feldspar recrystallized dynamically during at least part of the shearing history. Again similar to Zinsnock and Staller Sattel, the southernmost mylonites often show elongate coarse-grained quartz ribbons (Fig. 15a). Further north, the grain size of quartz is smaller due to subgrain rotation recrystallization, but feldspar still recrystallizes to form alternating quartz- and feldsparrich ribbons (Fig. 15b). However, the dynamic microstructure continued to develop along a retrograde path, as indicated by increasingly dominant chloritesericite assemblages, strong undulose extinction in quartz with associated well-developed deformation lamellae, local fine-grained quartz recrystallization and, as noted above, an eventual transition from ductile shear bands to discrete faults. The kinematics remained the same throughout this retrograde history, but it is not established if shearing was continuous or involved later reactivation of an existing fault zone. Although the location is not accurately given, it appears that sample AA15 of Borsi et al. (1973), a "muscovite pegmatitic orthogneiss", was taken from the prominent white coarse-grained pegmatites towards the northern end of the forestry road on this section. On muscovite separated from the pegmatites, Borsi et al. (1973) obtained $245 \pm 12$ Ma for the Rb-Sr system and $103 \pm 3 \mathrm{Ma}$ for $\mathrm{K}-\mathrm{Ar}$. The Cretaceous $\mathrm{K}-\mathrm{Ar}$ muscovite age is identical to that obtained by Stöckhert (1984) for similar pegmatites near Uttenheim, and is one of the main arguments for Cretaceous metamorphism and deformation in the block north of the DAV. However, these K/Ar ages could also be mixed ages between a Permian emplacement and an Oligocene overprint (see below). Indeed, syn- 
kinematic fibrous white mica growing between fractured K-feldspar from a mylonite in this same Weitental section gave an Rb-Sr microsampling age of 33.4 \pm 1.3 Ma (sample BG55; Müller 1998; Müller et al. 2000). Sinistral shearing therefore persisted until the Oligocene. Earlier sinistral shearing could still be Cretaceous in age, but the evidence remains indirect.
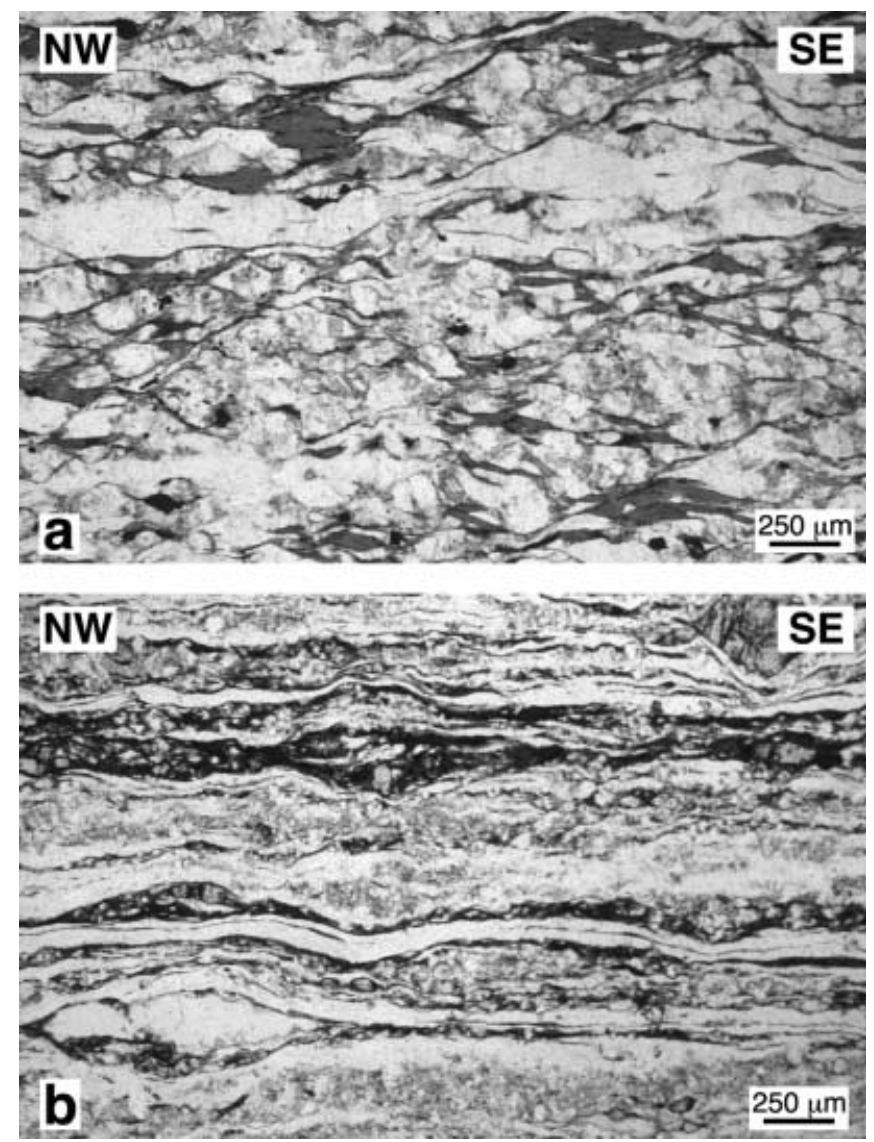

Fig. 15a, b DAV mylonites in the Weitental section (locality $\mathrm{N}$, Fig. 1). a Typical sample from the southernmost outcrops just north of the Periadriatic fault. Coarse-grained quartz ribbons alternating with more feldspar-rich layers are typical and very similar to samples from the southernmost parts of the sections at Staller Sattel (C) and Zinsnock (D). Biotite is (at least initially) stable in the well-developed sinistral shearbands which are transitional to discrete brittle Riedel faults on both the thinsection and outcrop scale. Foliation 048/42 (backrotated between discrete sinistral Riedel faults), lineation 120/15. b Laminated finer-grained mylonite from the forestry road section further north, with alternating quartz ribbons (partially recrystallized, mainly by a subgrain rotation mechanism) and recrystallized feldspar layers. Garnet forms porphyroclasts and is often fractured to form bookshelf structures. Sinistral sense of shear is clear from these bookshelf structures in garnet and larger feldspar porphyroclasts, from strong preferred orientation and oblique grain fabrics in quartz and from shear bands, in which biotite is initially stable but is subsequently partially replaced by chlorite. Strong undulose extinction and deformation lamellae in quartz also argue for a retrograde deformation path. Foliation $002 / 45$, lineation $264 / 02$

\section{Vals-Ochsensprung}

The Vals-Ochsensprung section (locations O-P, Fig. 1) has had a long history of geological interest, both for the excellent deformation microstructures (Sander 1948) and for the Periadriatic Rensen pluton and common dykes (Scolari and Zirpoli 1972; Nollau 1974; Barth et al. 1989). Of particular importance is that the dykes occur both in the Austroalpine and within the adjacent Tauern window at Ochsensprung. The overall deformation fabric is dominated by sinistral strike-slip shearing (in the current orientation), related to a near horizontal lineation and steeply $\mathrm{N}$ - to NW-dipping foliation. Two several-hundred-metre-wide bands of particularly intense sinistral shearing occur: one straddling the contact to the Tauern window and the other running approximately midway between the Rensen pluton and the Periadriatic fault (Fig. 1; Grollimund 1996). However, evidence for sinistral shearing is found irregularly distributed across the whole $\mathrm{N}-\mathrm{S}$ section and appears to reach as far as the Periadriatic fault itself, although the outcrop in the last few hundred metres to the Periadriatic fault is generally poor. There is a consistent gradient in microstructures related to this shearing, indicating increased temperatures towards the Tauern window, where the quartz microstructure is determined by advanced grain-boundary migration (Fig. 16).

Characteristic tourmaline-bearing pegmatites are isoclinally folded and mylonitized under conditions conducive to feldspar recrystallization and subsequently overprinted by a heterogeneous sinistral shear foliation and associated tight to isoclinal folds, with axes parallel to the stretching lineation (Grollimund 1996). The vergence of these latter folds is consistently antiform-to-N. This history is similar to that proposed by Kleinschrodt (1987) for the adjacent region to the east and by Stöckhert (1982) for the western side of the Tauferer valley. However, in practice, there is generally a single dominant schistosity observed and it is not clear which of these elements is dominant, or if, as is more likely, the main foliation represents the finite result of multiple reactivation with similar sinistral strike-slip kinematics.

A more sporadic overprint involving dextral strikeslip or top-to-SE reverse faulting is most obvious in the immediate vicinity of the Rensen pluton and just north of the Periadriatic fault. These faults are associated with very fine-grained quartz microstructures transitional to brittle behaviour (see previous discussion of movements related to the Periadriatic fault). The Rensen pluton itself and its associated aplite and pegmatite dykes and quartz veins crosscut the earlier sinistral shear fabric and are only affected by the later dextral transpressive structures. The dextral overprint is particularly clear at the northwestern contact south of Plattspitz (Fig. 1), where both the tonalite and the immediate country rock show clear dextral shear bands (Fig. 4) similar to the relationships across the 

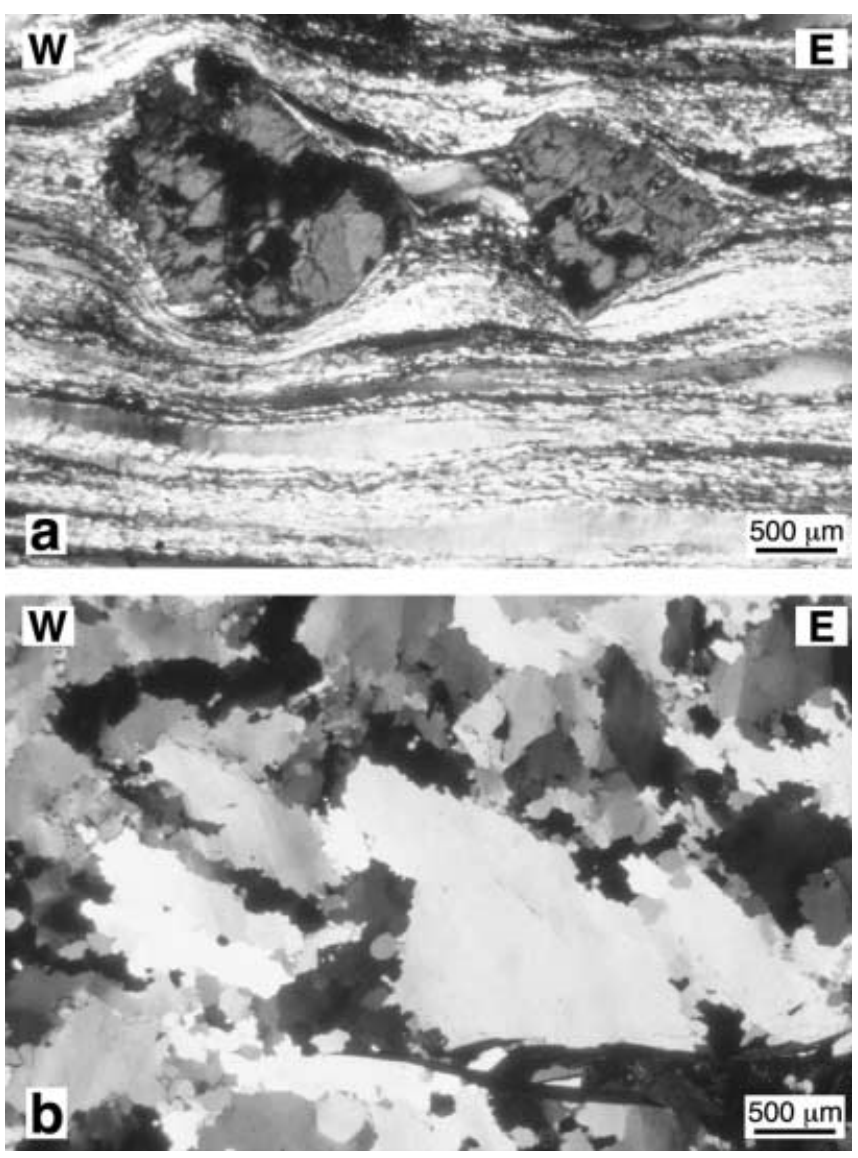

Fig. 16a, b Progressive change in quartz microstructure in the sinistral DAV mylonites from a south to b north. a Sample $1.5 \mathrm{~km}$ from the Tauern window contact, in the strongly mylonitic zone $\sim 500 \mathrm{~m}$ south of the Rensen pluton. Bookshelf structure in fractured feldspar showing sinistral shear sense, with fine-grained recrystallization of quartz by progressive subgrain rotation. Foliation 336/53, lineation 251/04, from near point $2285 \mathrm{~m}, 1.3 \mathrm{~km}$ direction $170^{\circ}$ from Plattspitz (BG69 from Grollimund 1996). b Sample $\sim 50 \mathrm{~m}$ from the Tauern window contact at Ochsensprung, showing exaggerated grain growth of quartz by grain boundary migration. Shear sense still sinistral from oblique fabric and preferred orientation. Foliation 356/54, lineation 266/13 (BG101 from Grollimund 1996)

contact described for the Stemmeringer Almbach (Fig. 10b). However, earlier dykes, which have never been found in the pluton itself, are locally strongly mylonitized with a sinistral shear sense. Both quartz and feldspar phenocrysts recrystallize by subgrain rotation. In one such dyke from near Plattspitz (Fig. 17a), north of the Rensen pluton, $\mathrm{Rb}-\mathrm{Sr}$ microsampling of large magmatic white mica and plagioclase phenocrysts yielded an age of $30.9 \pm 0.2 \mathrm{Ma}$ (sample BG169; Müller et al. 2000), which is considered to closely approximate the age of intrusion. Many other dykes are less intensely deformed (Fig. 17b), crosscut the external fabric at a low angle, and are, to different degrees, internally foliated parallel to the dyke walls. Kugel (1989) obtained ${ }^{40} \mathrm{Ar}-{ }^{39} \mathrm{Ar}$ total ages on primary and coarse-grained white mica from two "practi-
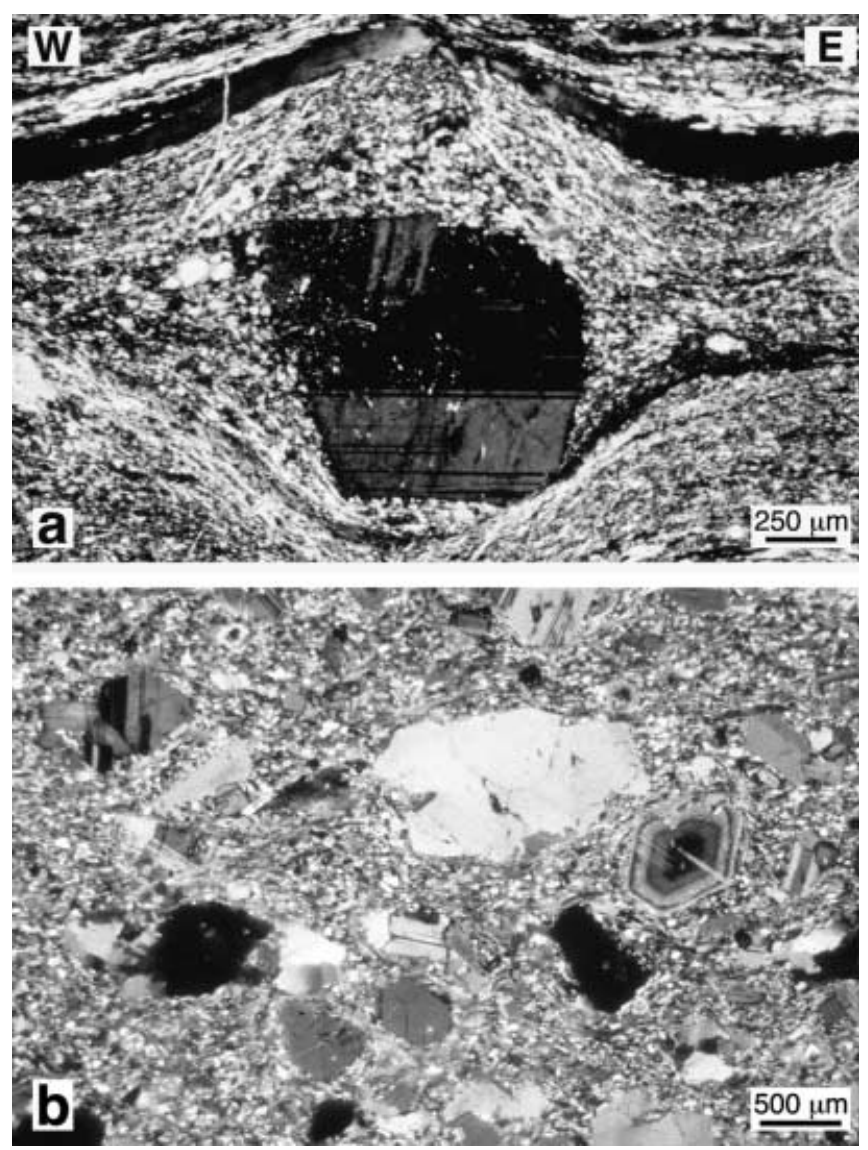

Fig. 17a, b Different microstructural aspect of Periadriatic dykes from the Plattspitz-Ochsensprung area. a Extreme (sinistral) mylonitization of the dated dyke BG169 (30.9 $\pm 0.2 \mathrm{Ma}$; Müller et al. 2000), showing quartz ribbons wrapping around a plagioclase porphyroclast. The plagioclase acts mainly as a rigid clast, without significant crystal-plastic deformation, but does extensively recrystallize to a fine-grained matrix in the tails to either side. Foliation 355/56, lineation 079/07. b The opposite extreme, namely a practically undeformed "rhyodacitic" dyke similar to those dated by Kugel (1989) as 30 Ma, i.e. only very

cally undeformed" rhyodacitic dykes of $29.9 \pm 0.5$ and $29.8 \pm 0.6 \mathrm{Ma}$. These results are indeed slightly younger than the $\mathrm{Rb}-\mathrm{Sr}$ age from the mylonitic dyke, but the difference lies within the error limits. In fact, both these sets of results are indistinguishable from the intrusion age of the main Rensen pluton (31.7-31.1 Ma; Barth et al. 1989), although field relationships suggest that the dykes immediately precede pluton emplacement. More basic dykes, commonly with amphibole phenocrysts, are practically undeformed. Scolari and Zirpoli (1972) noted that metamorphism of the dykes led to the formation of new biotite, spessartine garnet, albite and actinolite (in the more intermediate compositions), and suggested metamorphic conditions of approximately $450{ }^{\circ} \mathrm{C}$ and $400 \mathrm{MPa}$. 


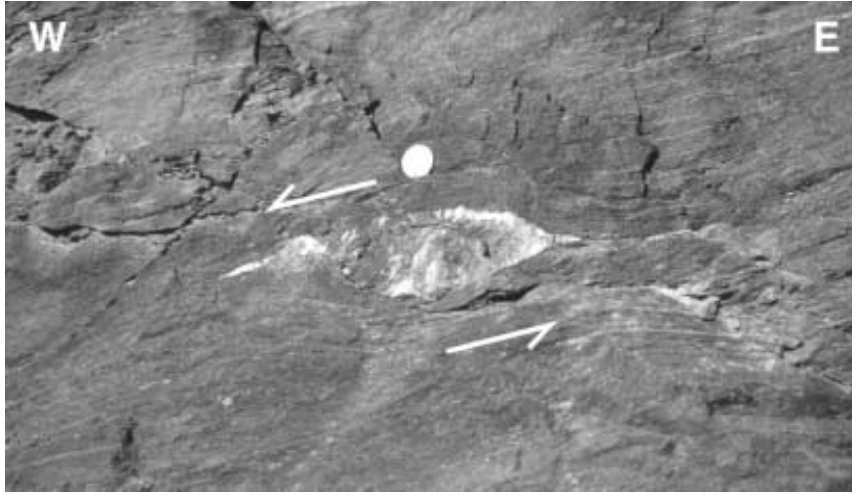

Fig. 18 Asymmetrical leucocratic boudin in prasinites (?Lower Austroalpine Matrei Zone; see Fig. 1), indicating sinistral shear sense. Locality is at the contact to the Tauern window, on the road section near Valgnaun, north of Mauls. View looking N, foliation $005 / 40$, lineation $285 / 25$

\section{Mauls-Sterzing}

As introduced in discussing the Periadriatic fault kinematics above, the effects of the dextral transpressive overprint are more common in the Mauls-Sterzing area (locations Q-T, Fig. 1), close to the Brenner fault and in the narrow Austroalpine zone between the Periadriatic fault and the Tauern window. However, although the overprint is fairly pervasive, remnant domains (especially in more feldspar-rich or amphibolitic units) preserve sinistral strike-slip kinematics (Stöckli 1995). As in the Ochsensprung section immediately to the east, there are two broad bands where sinistral shearing is particularly well developed, one across the Tauern window boundary (Fig. 18) and another 200-300 m north of the Mauls Triassic units.
Both the Mauls Triassic units and the underlying basement to the south did not exceed lowermost greenschist facies conditions during the Alpine history (maximum $300-350{ }^{\circ} \mathrm{C}$ from calcite-dolomite geothermometry; Stöckli 1995). Limestone-rich units in the Mauls Triassic are intensely mylonitized, whereas dolomitic units remained brittle, consistent with the interpreted metamorphic conditions. The mylonitic foliation (effectively parallel to bedding) and lineation are folded around upright, fairly open folds with axes plunging on average $20-30^{\circ}$ to the NE or ENE, and axial planes dipping steeply north. Both the northern and southern boundaries are tectonically overprinted by south- to southeast-directed reverse faults, probably coeval with the folding and consistent with continued N-S shortening during exhumation of the Tauern window.

By analogy with the adjacent Texel and Ötztal-Stubai units to the west, at least part of the sinistral movement in the Mauls area could be related to Late Cretaceous movements; however, part is certainly Oligocene in age. This is readily established from the

Fig. 19 Periadriatic dyke at climbing wall immediately below Sprechenstein castle (location S, Fig. 1), with arrowed notebook for scale. Note the strong external foliation that is partly transected by the intrusive contact (but with a parallel solid-state foliation continuous inside) and the well-developed sinistral shear bands that overprint the foliation both in the dyke and country rock. Dyke wall 167/74, country rock foliation 343/79, lineation 263/13. Overview of the dyke looking west; detail views are of horizontal sections. Locally, mylonitized quartz veins show a dextral sense, with very fine recrystallized grain size, probably related to the Brenner-Periadriatic fault overprint (Stöckli 1995). The two senses can even be observed in a single thin section: dextral in the fine-grained quartz layers but with sinistral shear bands preserved in the surrounding amphibolite country rock

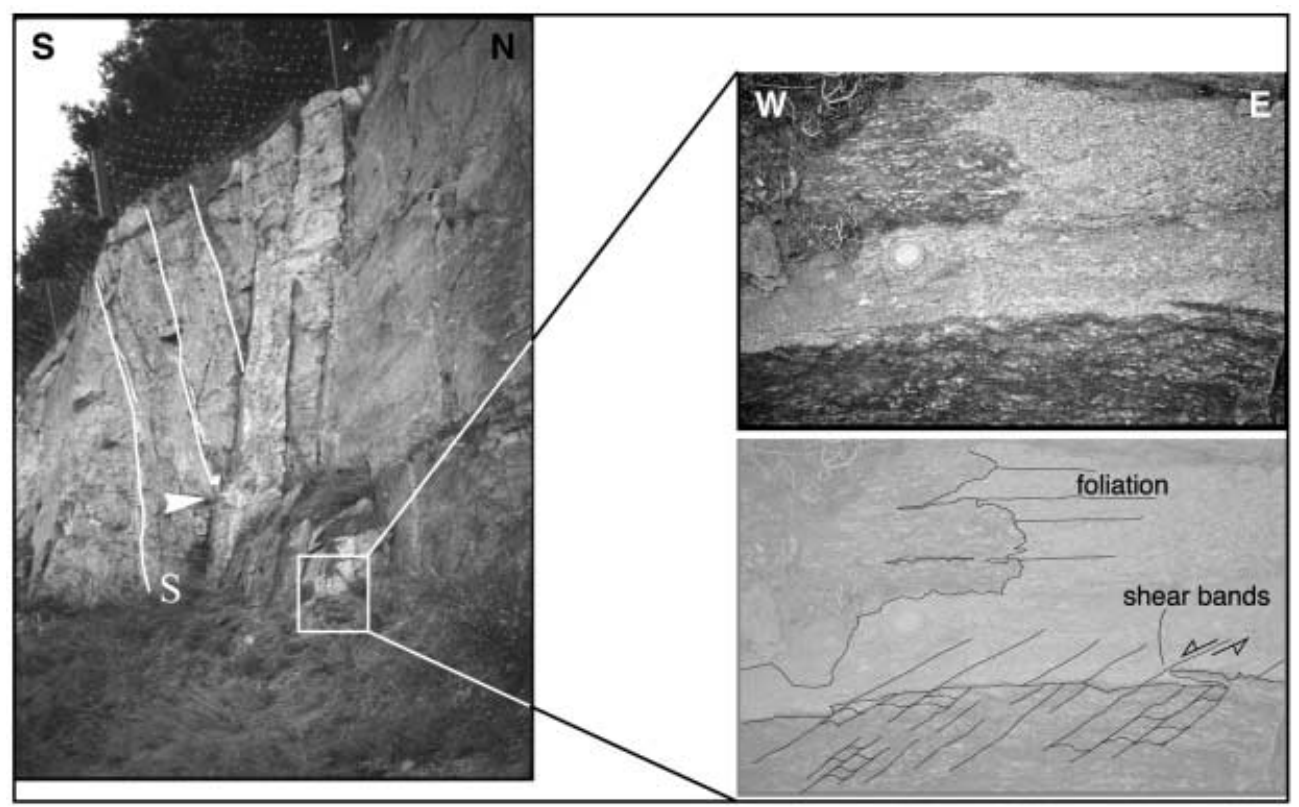



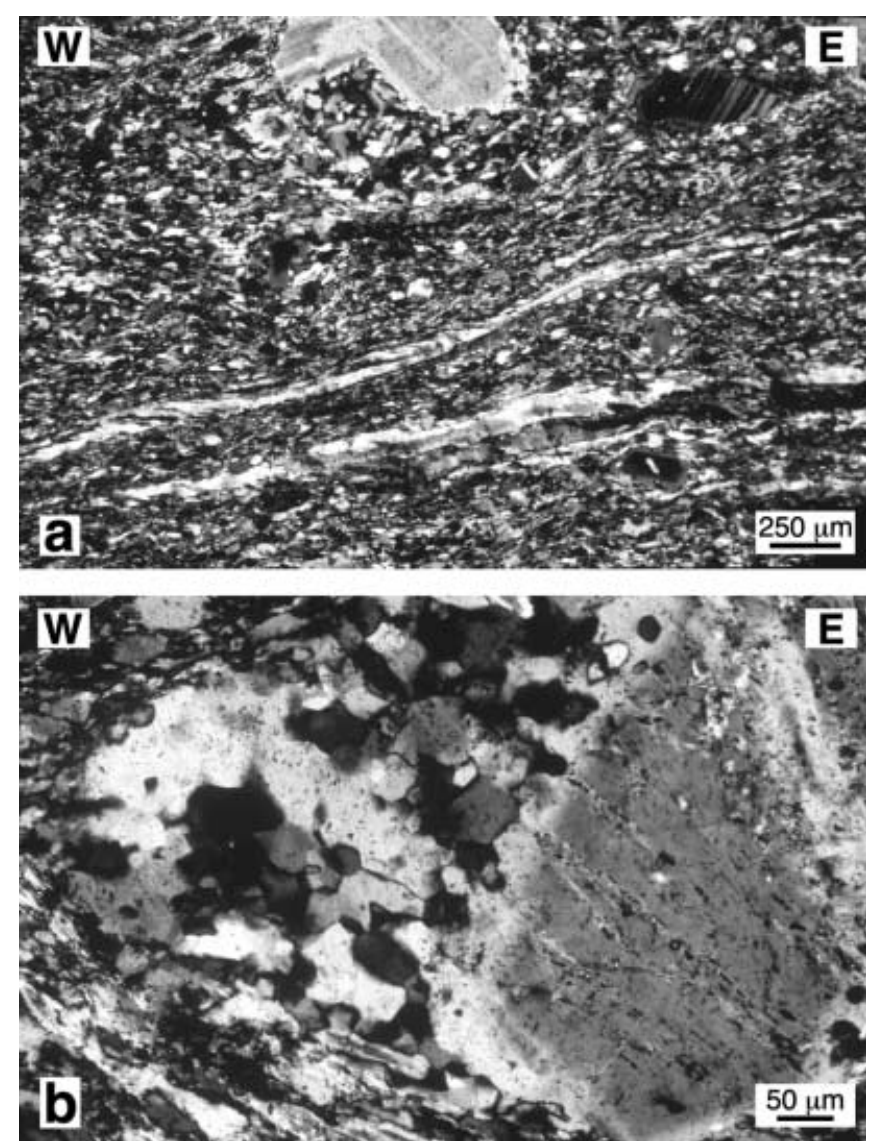

Fig. 20a, b Mylonitic fabric and plagioclase recrystallization in the Sprechenstein dyke. a Ribbon quartz development, with partial recrystallization by subgrain rotation, and plagioclase clast showing little evidence for crystal-plastic shape change but still partially recrystallized. b Close-up of plagioclase recrystallization by progressive subgrain rotation

relationship to fairly common Periadriatic dykes, such as that below the castle of Sprechenstein on the east wall of the Eisack valley (location S). This dyke transects the main mylonitic foliation in vertical profile, with the dyke dipping steeply SSE, whereas the foliation in the country rock dips steeply NNW (Fig. 3b, inset; Fig. 19). In horizontal section, pale-coloured quartz-feldspar rich ribbons are clearly transected by the dyke contact, but a parallel foliation continues into the dyke itself (Fig. 19). Sinistral shear bands are common to both dyke and country rock. Dyke intrusion has therefore occurred during continued sinistral shearing, although there is no constraint on the amount of time involved. It cannot be excluded that the external ribbon fabric is largely Cretaceous and was reactivated during the Oligocene sinistral shearing that produced the parallel foliation and lineation in the dyke. However, although mainly forming porphyroclasts, plagioclase in the dyke was capable of recrystallizing during mylonitization (Fig. 20), so the presence or absence of feldspar recrystallization cannot be
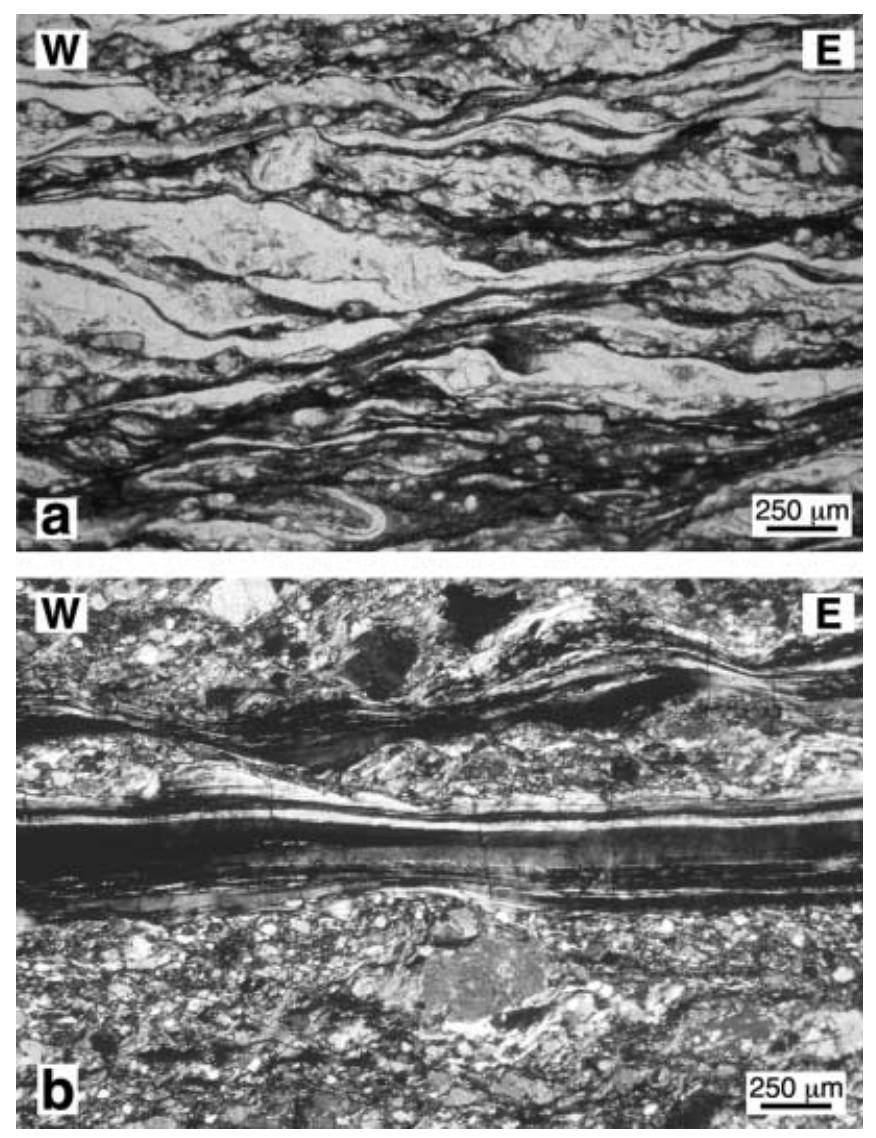

Fig. 21a, b Fabrics in the amphibolites from the dyke-bearing outcrops of a Reifenstein and $\mathbf{b}$ the Penserjoch road. a Sinistral mylonites with excellent shear bands in amphibole-bearing paragneiss immediately below the castle of Reifenstein (location $\mathrm{R}$ in Fig. 1). Ultrafine foliated brown layers with rounded clasts, both parallel to the foliation and to shear bands, could represent smeared-out pseudotachylytes. Approximately $50 \mathrm{~m}$ north of this outcrop, the more micaceous paragneisses and schists show common conjugate shear bands, but with sinistral sense dominant. Foliation 330/72, lineation 245/16. b Dextral mylonites from the northernmost part of the Penserjoch road outcrop (location T, Fig. 1). Note that the quartz recrystallization is very fine grained, similar to observations at the Sprechenstein location (Figs. 19, 20). However, continuous dextral shear bands in the adjacent amphibolite here show stable biotite and (fibrous) amphibole growth, so conditions at least initially were similar to those observed in the sinistral fabrics. Foliation 346/84, lineation $258 / 09$

used as a criterion for distinguishing Cretaceous higher-grade deformation.

The amphibolite-rich banded paragneiss country rock can be followed along strike across the Eisack valley, via the Reifenstein castle (location $R$ ), to a section along the Sterzing to Penserjoch road (location T). Dykes are present in all outcrops with similar angular relationships between external foliation and the dyke wall. Foliation within the dykes is wall-parallel with the same lineation direction as the country rocks (plunging $\sim 15^{\circ} \mathrm{SW}$ to WSW). In the dykes, biotite was stable during shearing and overgrowths of 
fine new garnet are observed on larger, presumably magmatic, garnets. Feldspar and large muscovite phenocrysts act mainly as rigid clasts during shearing, but plagioclase does partially recrystallize by subgrain rotation. In the country rock, both biotite and amphibole were stable during mylonitic deformation and shear band formation (Fig. 21), and feldspar deforms crystal-plastically and is extensively recrystallized, particularly in the amphibolite bands. A sinistral shear sense is predominant but not ubiquitous (Fig. 21). Conjugate shear bands are common and, in particular along the Penserjoch road section, sinistral senses may alternate with dextral senses. Dykes show the same shear sense as the adjacent country rock. In the more southerly dyke, near the beginning of the Penserjoch road section, the sense is dextral, whereas for those near the middle of the section it is sinistral. In one such sinistral dyke, prominent millimetre-sized euhedral muscovite and K-feldspar phenocrysts were dated

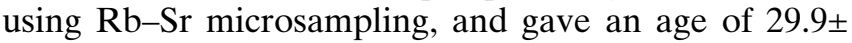
$0.3 \mathrm{Ma}$ (sample JP102; Müller 1998; Müller et al. 2000). This is considered to closely reflect the time of intrusion for these thin dykes, whose width does not exceed $\sim 0.5 \mathrm{~m}$ (Figs. 3, 19).

Although new biotite growth and incipient feldspar recrystallization can still be observed in examples displaying dextral shearing, quartz often recrystallizes by subgrain rotation to a (very) fine grain size (Fig. 21b) suggesting a progression from sinistral to dextral shearing during cooling. This is in agreement with the consistent overprint of sinistral by dextral fabrics observed in the Mauls area by Stöckli (1995) and the proposed regional change in kinematics at $\sim 30 \mathrm{Ma}$. However, in the Penserjoch road section a clear time relationship between sinistral and dextral shearing cannot be unequivocally established.

\section{"Old Alpine" or "Eoalpine" deformation}

The sequence of structural events established from geometric overprinting criteria in the areas of detailed mapping between Sterzing and the Vals valley is very similar to that reported by Stöckhert (1982, 1987), Kleinschrodt (1987) and Schulz (1994b) for the areas further east. The first of the fabrics is locally mylonitic and overprints the characteristic Permian tourmalinebearing pegmatites. This in itself does not exclude possible Permian (e.g. Müntener et al. 2000) or Jurassic deformation (e.g. Froitzheim and Eberli 1990), both of which occur regionally. Both Stöckhert (1984) and Borsi et al. (1973) interpreted K-Ar ages of $\sim 100 \mathrm{Ma}$ for muscovites from deformed pegmatites in the Uttenheim and Weitental areas as a record of Cretaceous metamorphism. These results are comparable to those in contiguous areas of the Middle Austroalpine units to the west (in the Texel, Schneeberg, Ötztal-Stubai and Brenner Mesozoic units) and to the east in Schober region (e.g. see the new Metamorphic
Map of the Alps; Frey et al. 1999). However, the $\mathrm{K}-\mathrm{Ar}$ bulk extraction technique cannot resolve mixed ages and therefore cannot establish the timing of events unequivocally. As noted above, for the whole Austroalpine region south of the Tauern window considered here, the main Alpine foliation strikes generally ENE, has a shallowly plunging stretching lineation, and where determinable, a sinistral shear sense in its current orientation. Except for the observation that this fabric overprints the Permian pegmatites and is in turn crosscut by the main Periadriatic plutons, direct field relationships place little constraint on the timing. It is established that at least some of the sinistral shearing overprints early Periadriatic dykes with ages around $30 \mathrm{Ma}$, and that direct $\mathrm{Rb}-\mathrm{Sr}$ dating of synkinematic white mica growth gives ages of between $\sim 30 \mathrm{Ma}$ at Stemmeringer Almbach and $\sim 33 \mathrm{Ma}$ near Weitental. Sinistral shearing certainly occurred in the mid-Oligocene. However, the ${ }^{40} \mathrm{Ar}-{ }^{39} \mathrm{Ar}$ age of $\sim 46 \mathrm{Ma}$ on pseudotachylyte parallel to but locally crosscutting DAV mylonites near Zinsnock establishes that at least some of the classic mylonites of the DAV must be of Eocene age or older. Müller et al. (2001) also obtained a Paleocene ${ }^{40} \mathrm{Ar}-{ }^{39} \mathrm{Ar}$ age of $\sim 60 \mathrm{Ma}$ (sample DAV881b) on a pseudotachylyte from $1.5 \mathrm{~km}$ south of the DAV trace in the Defereggen valley (location B, Fig. 1), providing further evidence for probable Paleogene activity.

However, distinguishing between mylonites of similar orientation, field aspect and kinematics is not straightforward. The most important differentiating characteristic proposed by Stöckhert (1982, 1984, 1987) and subsequent workers from the Erlangen group is the metamorphic grade during deformation. In this distinction, the Eoalpine mylonitization should have taken place under metamorphic conditions sufficient to allow recrystallization of both plagioclase and alkali feldspar, but in general not sufficient to reset the $\mathrm{Rb}-\mathrm{Sr}$ white mica isotopic system. Quartz should recrystallize by grain boundary migration, involving exaggerated grain growth, and be annealed at the end of the Eoalpine metamorphism, which outlasted Cretaceous deformation. In contrast, the Tertiary DAV movements should have developed under lower greenschist conditions, transitional towards the south to brittle deformation of quartz. This Tertiary deformation should be characterized by preserved dynamic microstructures still maintaining the dislocation substructure (seen optically as undulose extinction, subgrains, etc.) and involving grain-size reduction of quartz and fracture of feldspar. Unfortunately, this attractively clear distinction is difficult to apply in practice. Many thin sections, even from "classic" DAV localities, show ample evidence for initial deformation conditions conducive to feldspar crystal-plastic deformation and recrystallization, as well as grain boundary migration of quartz. These higher-grade fabrics show a retrograde transition to lower-grade fabrics with identical kinematics. Any hiatus in development 
is not discernible on purely geometric criteria. Indeed, particularly in the western regions towards Mauls where the regional gradation in isotopic mineral ages indicate a deeper level of exhumation during the more recent Tertiary history, sinistral shearing under midgreenschist facies metamorphism certainly outlasted emplacement of the Oligocene dykes. During mylonitization of these dykes there has been partial recrystallization of feldspar and stable growth of green-brown biotite, spessartine garnet and locally actinolitic amphibole (e.g. Scolari and Zirpoli 1972). Transient Oligocene high-temperature conditions were also attained in the aureoles of the major Periadriatic intrusives.

In general, the fabric crosscut by the Oligocene dykes does show much more extensive feldspar recrystallization and evidence for deformation under highergrade (?upper greenschist facies) conditions than the dykes themselves, where the original feldspar phenocrysts still behave largely as rigid clasts. The crosscut penetrative fabric is therefore potentially Cretaceous in age, reactivated during combined deformation with the dykes in the mid-Oligocene (Stöckhert 1982, 1984, 1987). However, the higher-grade sinistral deformation could also be Tertiary (Paleogene) in age, consistent with observations further east in the Karawanken mountains (e.g. see Fig. 7 of Polinski and Eisbacher 1992). At present, there is still no direct geochronological evidence for the age of the fabric crosscut by the dykes.

\section{Summary and discussion}

Alpine deformation north of the DAV produced heterogeneous shear zones that overprint the characteristic Permian pegmatites. Mylonites and ultramylonites developed at temperatures sufficient for feldspar recrystallization but cooled during deformation so that late shear bands are often marked by chlorite and are transitional to brittle fracture and pseudotachylyte development. Sense of shear is sinistral. The mylonitic fabric, together with the shear bands, is folded by upright folds with a consistent vergence giving antiform to the north. Two broad mylonitic zones were developed, one in the south (the DAV mylonites) and one towards the Tauern window boundary (the Speikboden mylonites). Early Periadriatic dykes of age 30 Ma, which often have phenocrysts (now porphyroclasts) of feldspar, muscovite, biotite and garnet, are variably deformed and in some cases strongly mylonitized. Biotite was stable and feldspar locally recrystallized by subgrain rotation during mylonitization of the dykes. The mylonites are crosscut by the main plutons and by directly associated quartz, aplite and pegmatite dykes, as well as by more intermediate to basic finegrained dykes, often containing randomly oriented hornblende phenocrysts. The mylonites are locally contact metamorphosed, but sinistral shearing of con- tact metamorphic andalusite during synkinematic muscovite and biotite growth is also observed. Sinistral shearing therefore continued during mid-Oligocene intrusion of the early dykes and growth of contact metamorphic minerals but was apparently terminated during intrusion and solidification of the main Rensen, Rieserferner and Zinsnock plutons.

An important microstructural observation, often reiterated in the sample descriptions above, is the incipient to advanced recrystallization of feldspar, mainly plagioclase. However, the temperature necessary to produce this apparent crystal-plastic deformation and recrystallization is not well established. Tullis and Yund (1987) consider that true subgrains are only produced in feldspar at the highest grade of metamorphism, when climb becomes easy (e.g. White 1975) and that any subgrains observed at lower grades should be suspected of arising from cataclastic flow. The same authors propose that the transition from cataclastic flow to dislocation creep should be complete by about middle to upper amphibolite grade. Under the optical microscope, recrystallization of feldspar in the study region appears to occur by a combination of subgrain rotation and bulge nucleation (e.g. Figs. 11c, 14b). Although feldspar recrystallizes, the metamorphic conditions were not sufficient to reset the $\mathrm{Rb}-\mathrm{Sr}$ isotopic system in existing white mica (see Villa 1998 for a discussion).

As noted above, folds in the mylonitic fabric have a consistent vergence of antiform to the north, towards the Tauern window. Prior to Neogene unroofing, the Tauern window was overlain by Middle Austroalpine units currently exposed to the west of the window in the hangingwall of the Brenner fault, i.e. the ÖtztalStubai crystalline and Brenner Mesozoic units. Cretaceous higher-grade metamorphism in this region only occurs in the footwall of a major Late Cretaceous to Tertiary low-angle normal fault, marked by a broad zone of mylonites developed on a retrograde path and preserving dynamic microstructures (Fügenschuh 1995; Fügenschuh et al., 2000) that clearly record a sense of shear that is top to ESE (Fügenschuh and Rockenschaub 1993). In the hangingwall of this Late Cretaceous fault, Upper Austroalpine units are preserved without significant Alpine metamorphism. Folding of this sequence as an envelope concordant with the Tauern window antiform would place it in a steep orientation south of the Tauern window, with a sinistral sense of shear relative to a flat lineation and a sharp jump to an Upper Austroalpine hangingwall further south, lacking penetrative Alpine overprint.

This is in accord with the observations in the Mauls area (Stöckli 1995), where in Alpine times both the Mauls Triassic units and the underlying basement to the south did not exceed lowermost greenschist facies conditions. Limestone-rich units in the Mauls Triassic are intensely mylonitized whereas dolomitic units remained brittle. This behaviour is identical to that observed in the northern Brenner Mesozoic unit (see 
Fügenschuh 1995; Fügenschuh et al., 2000). The mylonitic foliation and lineation in the Mauls Triassic limestones are now folded around upright, fairly open folds (see above). For a presumed originally flat-lying bedding orientation, the mylonitization of the more calcareous units corresponds to top-to-ESE movement (Stöckli 1995), again identical to that established in the Brenner Mesozoic units overlying the Ötztal-Stubai basement (Fügenschuh et al., 2000). By analogy, a least part of the sinistral movement in the Austroalpine to the north of the Mauls Triassic could be related to Late Cretaceous movements. In general, regional correlations and Cretaceous $\mathrm{K}-\mathrm{Ar}$ ages (Borsi et al. 1973; Stöckhert 1984) suggest that a part of the sinistral shearing (in the current orientation) observed in the Austroalpine south of the Tauern window could be of Late Cretaceous to Early Tertiary age, but the argument is still indirect.

Neubauer et al. (1995) consider that the Late Cretaceous exhumation of the Gleinalm metamorphic dome, to the east of the Tauern window, occurred within a releasing structure in a sinistral wrench corridor, consisting of a system of ductile shear zones including low-angle normal faults and steep sinistral tear faults. If this model were to be extended to the west into the region discussed here, the orientation of both the low-angle normal fault in the Ötztal-Stubai region and the steep sinistral shear zones south of the Tauern window could be original, with the steepening of the southern Tauern boundary occurring during the sinistral shearing. The folds in the mylonitic fabric with antiform-to-north vergence would reflect this steepening and have developed with axes near parallel to the stretching direction during progressive shear (e.g. Grujic and Mancktelow 1995). Recurrence of sinistral strike-slip shearing in the Tertiary may then have produced further folding, steepening and a stronger composite mylonitic foliation. Considering the time span involved, an episodic rather than continuous model is most likely, involving top-to-east normal faulting in the Late Cretaceous, subsequent folding, and further sinistral strike-slip shearing and folding in the Oligocene.

No evidence for sinistral overprint of the large Rensen and Rieserferner plutons could be established; instead, there is a major change in kinematics. Intrusion of the plutons and the tonalite lamellae along the Periadriatic fault was coeval with the development of a regional dextral transpressive regime. Subsequent exhumation through the brittle-ductile transition along the Periadriatic fault, with local development of pseudotachylytes, was coeval with exhumation of the Tauern window in the footwall of the Brenner normal fault at 20-17 Ma. Brittle faulting occurred on the Periadriatic fault itself, synthetic and antithetic Riedel shears, top-to-S(SE) reverse faults, top-down-to-E steep normal faults and NNE-trending sinistral (plus west side up) faults (parallel to the Giudicarie-Passeier fault). These structures are all consistent with
$\mathrm{N}-\mathrm{S}$ to NNW-SSE shortening and concomitant E-W extension.

The main displacement in the Neogene was localized on the discrete Periadriatic fault. Cataclastic zones developed both north and south of the elongate tonalite lamellae, but a jump in fission-track ages is only observed across the southern boundary to the Southalpine Brixen granodiorite (Fig. 2). From the fissiontrack results, the maximum vertical component of displacement across this quite discrete zone since the Miocene is of the order of 4-5 km. Displacement since the Oligocene could not have been much more since peak Alpine metamorphic conditions in the Austroalpine units immediately north of the Periadriatic fault never exceeded a temperature of $\sim 300^{\circ} \mathrm{C}$, with pressure estimated from fluid inclusion studies of $200 \mathrm{MPa}$ (Stöckhert 1982). The contact aureole of the Rieserferner pluton developed at pressures usually estimated in the range 200-300 MPa (Mager 1985; Schulz 1994b). These shallow depths also exclude any major vertical offset between the Rieserferner pluton and the Periadriatic fault since the mid-Oligocene. Reactivation of the DAV during Periadriatic movements with a dextral-transpressive sense, as indicated directly in the field (e.g. Fig. 6), may have been sufficient to influence the distribution of biotite and zircon fission-track mineral ages, but the vertical component could not have been very large. The lack of regional dextral shearing of the Tauern window contact, together with the continuity in distribution of the Oligocene dyke swarm across the boundary at Ochsensprung, also indicates that the Tauern window boundary has been effectively welded since at least the mid-Oligocene. The consistent angular relationship between the transected fabric and these dykes also indicates that the Tauern window boundary and concordant Austroalpine units were already steep to overturned prior to $30 \mathrm{Ma}$.

\section{Conclusion}

A dramatic change in regional kinematics, from sinistral transtensive to dextral transpressive occurred at $\sim 30 \mathrm{Ma}$, coeval with final emplacement and solidification of the Periadriatic Rensen and Rieserferner plutons. The time available for this transition was short. Dykes that immediately preceded intrusion of the main plutons were locally intensely sheared in a sinistral sense, as were contact metamorphic assemblages. However, $\mathrm{Rb}-\mathrm{Sr}$ microchrons on muscovite-feldspar pairs from the mylonitic dykes, and on muscovite-andalusite pairs from pull-aparts between andalusite porphyroclasts, give ages that are, within error limits, indistinguishable from those obtained from the plutons themselves. The time span for the transition is too short to be resolved with current geochronological methods, although the geometric sequence established from the field is consistent. The short time between intrusion of the sinistrally deformed dykes and the 
change in regional kinematics implies that strain rates must locally have been high, probably concentrated on the transient narrow thermally weakened zone around individual dykes.

The plutons generally have discordant contacts. When they are sheared, the sense of shear is dextral (with the exception of discrete antithetic Riedel faults, usually trending more NE; see below) and only solidstate deformation related to the Periadriatic dextral transpression has been observed to overprint the main plutonic bodies. Faults in the plutons are transitional from narrow low-grade shear zones, often located along pre-existing quartz veins and developing (and preserving) fine-grained recrystallized quartz microstructures, to discrete brittle faults. In the region around Sterzing in the southwest, where Neogene exhumation has been greatest within the immediate footwall of the Brenner normal fault, the degree of dextral overprint is also greater and is locally pervasive. In the Mauls area, lower-grade dextral fabrics consistently overprint higher-grade sinistral fabrics (Stöckli 1995), but further west, towards Sterzing, the distinction in timing between sinistral and dextral shearing is not so unequivocal. Oligocene dykes are mylonitized with both sinistral and dextral senses and conjugate shear bands are also common in the generally mylonitic country rock. Here at least, where the Austroalpine zone between the Tauern window and the Southern Alps is narrowest, an overlap in time between the sinistral and dextral shearing (and therefore more coaxial overall kinematics) cannot be excluded. The combination would produce an overall $\mathrm{N}-\mathrm{S}$ shortening and E-W extension, consistent with the regional Oligocene-Miocene kinematics. However, particularly around the Rensen and Rieserferner plutons, where the minor and major intrusives provide better relative time constraint, a rapid transition from regional sinistral to dextral kinematics seems to be well established. Caution is required, however, since sinistral Riedel shears antithetic to the main Periadriatic fault are locally important. They are recognizable from the preserved fine-grained microstructure, often transitional to brittle faulting and pseudotachylyte formation, which typically give ages of $20-17 \mathrm{Ma}$.

In the region considered here, previous authors have distinguished between an "Old Alpine" or "Eoalpine" higher-grade metamorphic and deformational event of proposed Late Cretaceous age and sinistral shearing related to the DAV, the age of which was somewhat controversial. However, since the whole generally retrograde deformation history prior to intrusion of the Periadriatic plutons has apparently occurred under a very similar kinematic regime (sinistral in the current orientation) and many of the "classic" DAV localities, on careful scrutiny, show evidence of initial conditions conducive to feldspar crystal-plasticity and dynamic recrystallization, the separation into two distinct episodes is not clear. The majority of mylonites have initially developed under middle- to upper-greenschist facies conditions, with biotite stable both in pressure shadows around older (presumably Hercynian) garnet porphyroclasts and in shear bands and with incipient to advanced crystal plastic deformation, subgrain formation and, in some cases, extensive recrystallization of feldspar. This is true for both the country rock and the group of mylonitized mid-Oligocene dykes. There is a gradation to increasing metamorphic conditions during deformation towards and across the Tauern window boundary during sinistral shearing. The common foliation is consistently transected at a low angle by subvertical Periadriatic dykes, found in the Austroalpine and in the adjacent Tauern window. Both the foliation and concordant Tauern window boundary must therefore have had a steep to overturned orientation before the mid-Oligocene.

The overprinting relationship with the dykes demonstrates that sinistral shearing was active until $30 \mathrm{Ma}$ and direct $\mathrm{Rb}-\mathrm{Sr}$ dating of synkinematic muscovite extends the activity back to $\sim 33 \mathrm{Ma}$. The age of pseudotachylytes associated with DAV mylonites extends the range still further back to the Early Tertiary and regional correlation with the Middle Austroalpine units further west suggests an extension into the Late Cretaceous. However, these constraints are much more indirect and give no information on the temporal continuity of movement. The sinistral shear sense in the current orientation could result from rotation of an initially low-angle (?Late Cretaceous to Early Tertiary) normal shear zone with top-to-east sense (as established in the Ötztal-Stubai area; Fügenschuh 1995; Fügenschuh et al., 2000) during subsequent folding. It is also possible that both orientations were more or less coeval within a broad wrench corridor. A sinistral strike-slip corridor along the southern boundary to the Tauern window in the Late Cretaceous to Eocene would be consistent with observations further east in the Karawanken Mountains by Polinski and Eisbacher (1992), in the Graz Paleozoic by Ratschbacher et al. (1991c) and in the Gleinalm area by Neubauer et al. (1995). It has also been previously proposed in several regional models for Alpine tectonics around the Cretaceous-Tertiary boundary. Froitzheim et al. $(1996,1997)$ noted that the west- to northwest-directed thrusting and subsequent normal faulting in the opposite direction were not recorded in the Southern Alps and proposed a roll-back model bounded to the south by a sinistral zone through the region considered here. The plate-tectonics reconstructions of Stampfli et al. (1998) also require a similar major zone of sinistral displacement during Late Cretaceous. This study establishes that sinistral kinematics prior to the mid-Oligocene is widespread south of the Tauern window, and that the steep orientation was already attained prior to this time. Sinistral shearing continued (intermittently?) until $\sim 30 \mathrm{Ma}$, when there was a rapid transition to the Periadriatic dextral transpressive regime that has since been maintained. 


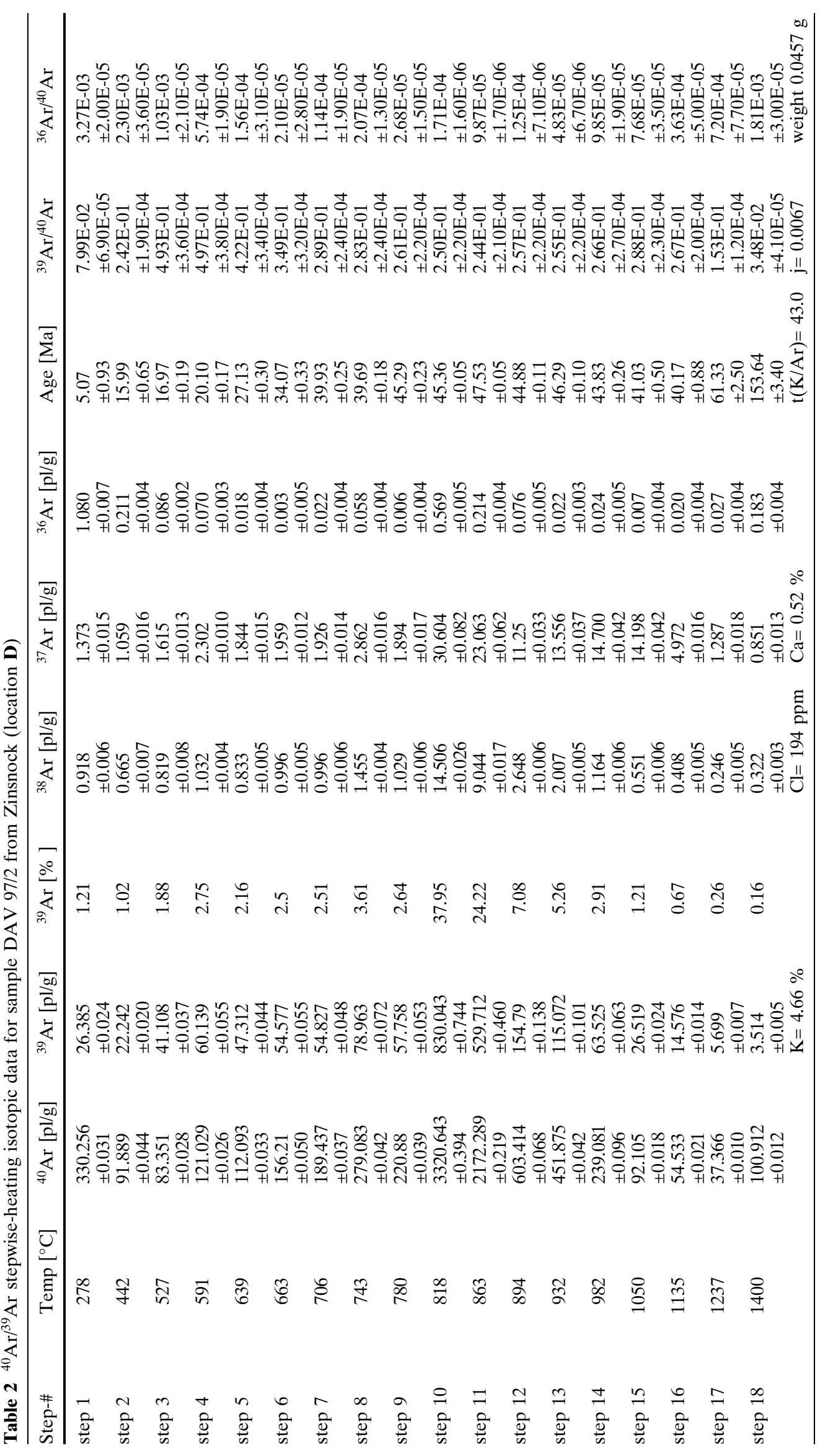


Acknowledgements Thanks to A. Meier for help in dating the pseudotachylytes, and to B. Schulz and B. Cesare for introducing us to the Staller Sattel and Hochhorn sections, respectively. Thanks also to L. Ratschbacher and B. Stöckhert for thorough and constructive reviews. Financial support for W. Müller from ETH grant 0-20-797-94, for B. Fügenschuh from ETH grant $0-20-479-91$ and for G. Viola from ETH grant $0-20-211-96$ is gratefully acknowledged.

\section{References}

Agterberg FP (1961) Tectonics of the crystalline basement of the Dolomites in northern Italy. Geol Ultraiectina 8:1-232

Barth S, Oberli F, Meier M (1989) U-Th-Pb systematics of morphologically characterized zircon and allanite: a high resolution isotopic study of the Alpine Rensen pluton. Earth Planet Sci Lett 95:235-254

Behrmann JH (1988) Crustal-scale extension in a convergent orogen: the Sterzing-Steinach mylonite zone in the Eastern Alps. Geodin Acta 2:63-73

Bianchi A (1934) Studi petrografici sull'Alto Adige orientale e regioni limitrofe. Mem Ist Geol Univ Padova 10:1-243

Blanckenburg F von, Kagami H, Deutsch A, Oberli F, Meier M, Wiedenbeck M, Barth S, Fischer H (1998) The origin of Alpine plutons along the Periadriatic Lineament. Schweiz Mineral Petrogr Mitt 78:55-66

Borsi S, Del Moro A, Ferrara G (1972) Età radiometriche delle rocce intrusive del massiccio di Bressanone-Ivigna-Monte Croce (Alto Adige). Boll Soc Geol Ital 91:387-406

Borsi S, Del Moro A, Sassi FP, Zirpoli G (1973) Metamorphic evolution of the Austridic rocks to the south of the Tauern Window (Eastern Alps): radiometric and geopetrological data. Mem Soc Geol Ital 12:549-571

Borsi S, Del Moro A, Sassi FP, Zanferrari A, Zirpoli G (1978a) New geopetrologic and radiometric data on the Alpine history of the Austridic continental margin south of the Tauern Window (Eastern Alps). Mem Sci Geol Univ Padova 32:1-17

Borsi S, Del Moro A, Sassi FP, Zirpoli G (1978b) On the age of the Vedrette di Ries (Rieserferner) massif and its geodynamic significance. Geol Rundsch 68:41-60

Borsi S, Del Moro A, Sassi FP, Visona D, Zirpoli G (1980) On the existence of Hercynian aplites and pegmatites in the lower Aurina Valley (Ahrntal, Austrides, Eastern Alps). N Jahrb Mineral Mh 11:501-514

Bradbury HJ, Nolen-Hoeksema MC (1985) The Lepontine Alps as an evolving metamorphic core complex during A-type subduction: evidence from heat flow, mineral cooling ages and tectonic model. Tectonics 4:187-211

Cesare B (1999) Multi-stage pseudomorphic replacement of garnet during polymetamorphism. 1. Microstructures and their interpretation. J Metamorph Geol 17:723-734

Dal Piaz G (1934) Studi geologici sull'Alto Adige orientale e regioni limitrofe. Mem Ist Geol Univ Padova 10:1-238

Decker K, Peresson H (1996) Tertiary kinematics in the AlpineCarpathian-Pannonian system: links between thrusting, transform faulting and crustal extension. In: Wessely G, Liebl W (eds) Oil and gas in Alpidic thrustbelts and basins of Central and Eastern Europe. Eur. Assoc Petrol Geoscientists Spec Publ 5:69-77

Del Moro A, Notarpietro A (1987) Rb-Sr geochemistry of some Hercynian granitoids overprinted by eo-Alpine metamorphism in the Upper Valtellina, Central Alps. Schweiz Mineral Petrogr Mitt 67:295-306

Del Moro A, Pardini G, Quercioli C, Villa IM, Callegari E (1983) $\mathrm{Rb} / \mathrm{Sr}$ and $\mathrm{K} / \mathrm{Ar}$ chronology of Adamello granitoids, southern Alps. Mem Soc Geol Ital 26:285-299

Dunkl I, Demeny A (1997) Exhumation of the Rechnitz Window at the border of the Eastern Alps and Pannonian Basin during Neogene extension. Tectonophysics 272:197-211
Fodor L, Jelen B, Marton E, Skaberne D, Car J, Vrabec M (1998) Miocene-Pliocene tectonic evolution of the Slovenian Periadriatic fault: implications for Alpine-Carpathian extrusion models. Tectonics 17:690-708

Frank W, Alber J, Thöni M (1977) Jungalpine K/Ar-Alter von Hellglimmern aus dem Permotriaszug von Mauls-Penser Joch (Südtirol). Anz Österr Akad Wiss Math-Naturw Kl 7:102-107

Frey M, Desmons J, Neubauer F (1999) The new metamorphic map of the Alps: introduction. Schweiz Mineral Petrogr Mitt 79:1-4

Frisch W (1984) Sedimentological response to late Mesozoic subduction in the Penninic windows of the Eastern Alps. Geol Rundsch 73:33-45

Frisch W, Neubauer F, Satir M (1984) Concepts of the evolution of the Austroalpine basement complex (Eastern Alps) during the Caledonian-Variscan cycle. Geol Rundsch 73:47-68

Frisch W, Gommeringer K, Kelm U, Popp F (1987) The upper Bündner Schiefer of the Tauern Window: a key to understanding Eoalpine orogenic processes in the Eastern Alps. In: Flügel HW, Faupl P (eds) Geodynamics of the Eastern Alps. Deuticke, Vienna, pp 55-69

Froitzheim N, Eberli GP (1990) Extensional detachment faulting in the evolution of a Tethys passive continental margin, Eastern Alps, Switzerland. Geol Soc Am Bull 102:1297-1308

Froitzheim N, Schmid SM, Frey M (1996) Mesozoic paleogeography and the timing of eclogite-facies metamorphism in the Alps: a working hypothesis. Eclog Geol Helv 89:81-110

Froitzheim N, Conti P, van Daalen M (1997) Late Cretaceous, synorogenic, low-angle normal faulting along the Schlinig fault (Switzerland, Italy, Austria) and its significance for the tectonics of the Eastern Alps. Tectonophysics 280:267-293

Fügenschuh B (1995) Thermal and kinematic history of the Brenner Area (Eastern Alps, Tyrol). PhD thesis, ETH, Zürich, 226 pp

Fügenschuh B, Rockenschaub M (1993) Deformations in the hangingwall of the Brenner Fault Zone. Terra Abstr 5:165

Fügenschuh B, Seward D, Mancktelow N (1997) Exhumation in a convergent orogen: the western Tauern Window. Terra Nova 9:213-217

Fügenschuh B, Mancktelow NS, Seward D (2000) The Cretaceous to Neogene cooling and exhumation history of the Oetztal-Stubai basement complex, Eastern Alps: a structural and fission-track study. Tectonics 19:905-918

Genser J, Neubauer F (1988) Low angle normal faults at the eastern margin of the Tauern Window (Eastern Alps). Mitt Österr Geol Ges 81:233-243

Grollimund B (1996) Tektonik südlich des westlichen Tauernfensters (Valsertal, Südtirol). Diploma Thesis, ETH, Zürich, $173 \mathrm{pp}$

Grujic D, Mancktelow NS (1995) Folds with axes parallel to the extension direction: an experimental study. J Struct Geol 17:279-291

Grundmann G, Morteani G (1985) The young uplift and thermal history of the Central Eastern Alps (Austria, Italy), evidence from apatite fission track ages. Jahrb Geol B-A Wien 128:197-216

Hammerschmidt $\mathrm{K}$ (1982) $\mathrm{K} / \mathrm{Ar}$ and ${ }^{40} \mathrm{Ar} /{ }^{39} \mathrm{Ar}$ age resolution from illites of the Trias of Mauls; Mesozoic cover of the Austroalpine basement, Eastern Alps (South Tyrol). Schweiz Mineral Petrogr Mitt 62:113-133

Henry B (1975) Microtectonique et anisotropie de susceptibilite magnetique du massif tonalitique des Riesenferner-Vedrette Ries (Frontiere Italo-Autrichienne). Tectonophysics 27:155-165

Hofmann K-H, Kleinschrodt R, Lippert R, Mager D, Stöckhert B (1983) Geologische Karte des Altkristallins südlich des Tauernfensters zwischen Pfunderer Tal und Tauferer Tal (Südtirol). Schlern 57:572-590 
Hoinkes G, Purtscheller F, Tessadri R (1982) Polymetamorphose im Ostalpin westlich der Tauern (Ötztaler Masse, Schneeberger Zug, Brennermesozoikum): Zusammenfassung der petrographischen Neuergebnisse. Geol Paläontol Mitt Innsbruck 12:95-113

Hoinkes G, Kostner A, Thöni M (1991) Petrologic constraints for Eoalpine eclogite facies metamorphism in the Austroalpine Oetztal basement. Mineral Petrol 43:237-254

Kelley SP, Reddy SM, Maddock R (1994) Laser-probe ${ }^{40} \mathrm{Ar} /{ }^{39} \mathrm{Ar}$ investigation of a pseudotachylyte and its host rock from the Outer Isles Thrust, Scotland. Geology 22:443-446

Kleinschrodt R (1987) Quarzkorngefügeanalyse im Altkristallin südlich des westlichen Tauernfensters (Südtirol/Italien). Erlanger Geol Abh 114:1-82

Kugel T (1989) Geologie, Mineralogie und Geochemie von Ganggesteinen am Südwestrand des Tauernfensters. Diploma Thesis, Univ Tübingen, $146 \mathrm{pp}$

Laubscher HP (1983) The late Alpine (Periadriatic) intrusions and the Insubric Line. Mem Soc Geol Ital 26:21-30

Mager D (1985) Geologische und petrographische Untersuchungen am Südrand des Riesenferner-Plutons (Südtirol) unter Berücksichtigung des Intrusionsmechanismus. PhD thesis, Univ Erlangen, $182 \mathrm{pp}$

Magloughlin JF, Spray JG (1992) Frictional melting processes and products in geological materials: introduction and discussion. Tectonophysics 204:197-204

Manatschal G (1999) Fluid- and reaction-assisted low-angle normal faulting: evidence from rift-related brittle fault rocks in the Alps (Err Nappe, eastern Switzerland). J Struct Geol 21:777-793

Mancktelow NS, Meier A, Viola G, Müller W, Fügenschuh B, Seward D, Villa IM (1999) The Periadriatic and adjacent fault systems in the Eastern Alps south and west of the Tauern Window. Tübinger Geowiss Arb Series A 52:7-9

Marrett R, Allmendinger RW (1990) Kinematic analysis of fault-slip data. J Struct Geol 12:973-986

Martin S, Prosser G, Morten L (1993) Tectono-magmatic evolution of sheeted plutonic bodies along the north Giudicarie line (northern Italy). Geol Rundsch 82:51-66

Merle O, Cobbold PR, Schmid S (1989) Tertiary kinematics in the Lepontine dome. In: Coward MP, Dietrich D, Park RG (eds) Alpine tectonics. Geol Soc London Spec Publ 45:113-134

Müller W (1998) Dating of deformation using microsampling techniques: the evolution of the Periadriatic fault system (Alps). PhD thesis, ETH, Zürich, $135 \mathrm{pp}$

Müller W, Mancktelow NS, Meier M (2000) Rb-Sr microchrons of synkinematic mica in mylonites: an example from the DAV fault of the Eastern Alps. Earth Planet Sci Lett 180:385-397

Müller W, Prosser G, Mancktelow NS, Villa IM, Kelley SP, Viola G, Oberli F (2001) Geochronological constraints on the evolution of the Periadriatic Fault System (Alps). Int J Earth Sci DOI 10.1007/s005310000187 (this issue)

Müntener O, Hermann J, Trommsdorff V (2000) Cooling history and exhumation of lower crustal granulite and Upper Mantle (Malenco, Eastern Central Alps). J Petrol 41:175-200

Neubauer F, Dallmeyer RD, Dunkl I, Schirnik D (1995) Late Cretaceous exhumation of the metamorphic Gleinalm Dome, Eastern Alps: kinematics, cooling history and sedimentary response in a sinistral wrench corridor. Tectonophysics 242 : 79-98

Neubauer F, Hoinkes G, Sassi FP, Handler R, Hock V, Koller F, Frank W (1999) Pre-Alpine metamorphism of the Eastern Alps. Schweiz Mineral Petrogr Mitt 79:41-62

Nollau G (1969) Kleintektonische Strukturen am Südwestrand des Tauernfensters und ihre Beziehung in grosstektonische Konzepte. Geol Rundsch 58:755-788

Nollau G (1974) Petrographische und tektonische Untersuchungen am periadriatischen Rensengranit in Südtirol. Erlanger Geol Abh 98:1-92
Polinski RK, Eisbacher GH (1992) Deformation partitioning during polyphase oblique convergence in the Karawanken Mountains, southeastern Alps. J Struct Geol 14:1203-1213

Ratschbacher L, Frisch W, Neubauer F, Schmid SM, Neugebauer J (1989) Extension in compressional orogenic belts: the Eastern Alps. Geology 17:404-407

Ratschbacher L, Behrmann JH, Pahr A (1990) Penninic windows at the eastern end of the Alps and their relation to the intra-Carpathian basins. Tectonophysics 172:91-105

Ratschbacher L, Merle O, Davy P, Cobbold P (1991a) Lateral extrusion in the eastern Alps. Part I: Boundary conditions and experiments scaled for gravity. Tectonics 10:245-256

Ratschbacher L, Frisch W, Linzer H-G (1991b) Lateral extrusion in the eastern Alps. Part II: Structural analysis. Tectonics 10:257-271

Ratschbacher L, Wenk H-R, Sintubin M (1991c) Calcite textures: examples from nappes with strain-path partitioning. J Struct Geol 13:369-384

Rudolph J (1982) Tieferes Tertiär im oberen Fimbertal, Unterengadiner Fenster. N Jahrb Geol Paläontol Mh 1982/83:181-183

Sander B (1929) Erläuterungen zur geologischen Karte des Brixener und Meraner Gebiets. Schlernschriften 16:1-111

Sander B (1948) Einführung in die Gefügekunde der geologischen Körper (two volumes). Springer, Berlin Heidelberg New York

Sassi FP, Zanferrari A, Zirpoli G, Borsi S, Del Moro A (1974) The Austrides to the south of the Tauern Window and the periadriatic lineament between Mules and Mauthen. N Jahrb Geol Paläontol Mh 1974:421-434

Sassi FP, Borsi S, Del Moro A, Zanferrari A, Zirpoli G (1978) Contribution to the geodynamic interpretations in the Eastern Alps. In: Cloos H, Roeder D, Schmidt K (eds) Alps Apennines Hellenides. Schweizerbart'sche, Stuttgart, pp 154-160

Schmid SM, Aebli HR, Heller F, Zingg A (1989) The role of the Periadriatic Line in the tectonic evolution of the Alps. In: Coward MP, Dietrich D, Park RG (eds) Alpine tectonics. Geol Soc London Spec Publ 45:153-171

Schulz B (1988) Deformation, Metamorphose und Petrographie im ostalpinen Altkristallin südlich des Tauernfensters (südliche Deferegger Alpen, Österreich). PhD thesis, Univ Erlangen, $133 \mathrm{pp}$

Schulz B (1989) Jungalpidische Gefügeentwicklung entlang der Defereggen-Antholz-Vals-Linie (Osttirol, Österreich). Jahrb Geol B-A Wien 132:775-789

Schulz B (1994a) Geologische Karte des Altkristallins östlich des Tauferer Tals (Südtirol). Erlanger Geol Abh 124:1-28

Schulz B (1994b) Microstructural evolution of metapelites from the Austroalpine basement north of Staller Sattel during preAlpine and Alpine deformation and metamorphism (eastern Tyrol, Austria). Jahrb Geol B-A Wien 137:197-212

Schuster R, Scharbert S, Abart R (1999) Permo-Triassic crustal extension during opening of the Neotethyan ocean in the Austroalpine-South Alpine realm. Tübinger Geowiss Arb Series A 52:5-6

Scolari A, Zirpoli G (1972) Filoni tardoalpini metamorfici negli scisti austridici e pennidici della Val di Valles (Alto Adige). Mem Ist Geol Mineral Univ Padova 29:1-32

Selverstone J (1988) Evidence for east-west crustal extension in the Eastern Alps: implications for the unroofing history of the Tauern Window. Tectonics 7:87-105

Sibson RH (1975) Generation of pseudotachylite by ancient seismic faulting. Geophys J R Astron Soc 43:775-794

Stampfli GM, Mosar J, Marquer D, Marchant R, Baudin T, Borel G (1998) Subduction and obduction processes in the Swiss Alps. Tectonophysics 296:159-204

Stöckhert B (1982) Deformation und retrograde Metamorphose im Altkristallin S' des westlichen Tauernfensters (Südtirol). $\mathrm{PhD}$ thesis, Univ Erlangen, $214 \mathrm{pp}$ 
Stöckhert B (1984) K-Ar determinations on muscovites and phengites from deformed pegmatites, and the minimum age of the Old Alpine deformation in the Austridic basement to the south of the western Tauern Window (Ahrn Valley, southern Tyrol, Eastern Alps). N Jahrb Mineral Abh 150:103-120

Stöckhert B (1985) Pre-Alpine history of the Austridic basement to the south of the western Tauern Window (southern Tyrol, Italy): Caledonian versus Hercynian event. N Jahrb Geol Paläontol Mh 1985:618-642

Stöckhert B (1987) Das Uttenheimer Pegmatit-Feld (Ostalpines Altkristallin, Südtirol). Genese und alpine Überprägung. Erlanger Geol Abh 114:83-106

Stöckhert B, Brix MR, Kleinschrodt R, Hurford AJ, Wirth R (1999) Thermochronometry and microstructures of quartz: a comparison with experimental flow laws and predictions on the temperature of the brittle-plastic transition. J Struct Geol 21:351-369

Stöckli DF (1995) Tectonics SW of the Tauern Window (Mauls area, Südtirol). Diploma thesis, ETH, Zürich, 270 pp

Stöckli DF, Fügenschuh B (1995) Neogene tectonics SW of the Tauern Window. Second Workshop on Alpine Geology, abstract volume, Basel, pp 155-156
Thöni M (1981) Degree and evolution of the Alpine metamorphism in the Austroalpine Unit W of the Hohe Tauern in the light of $\mathrm{K} / \mathrm{Ar}$ and $\mathrm{Rb} / \mathrm{Sr}$ age determinations on micas. Jahrb Geol B-A Wien 124:111-174

Tollmann A (1959) Der Deckenbau der Ostalpen auf Grund der Neuuntersuchungen des zentralalpinen Mesozoikums. Mitt Ges Geol Bergbaustud Wien 10:1-62

Tollmann A (1963) Ostalpensynthese. Deuticke, Vienna

Tollmann A (1977) Geologie von Österreich, I, Die Zentralalpen. Deuticke, Vienna

Tullis J, Yund RA (1987) Transition from cataclastic flow to dislocation creep of feldspar: mechanisms and microstructures. Geology 15:606-609

Villa IM (1998) Isotopic closure. Terra Nova 10:42-47

Viola G (2000) Kinematics and timing of the Periadriatic fault system in the Giudicarie region (central-eastern Alps). Ph D Thesis, ETH, Zürich, 205 pp

Waibel AF, Frisch W (1989) The Lower Engadine Window: sediment deposition and accretion in relation to the plate-tectonic evolution of the Eastern Alps. Tectonophysics 162:229-241

White S (1975) Tectonic deformation and recrystallization of oligoclase. Contrib Mineral Petrol 50:287-304 